\title{
Alantolactone enhances gemcitabine sensitivity of lung cancer cells through the reactive oxygen species-mediated endoplasmic reticulum stress and Akt/GSK3 $\beta$ pathway
}

\author{
JIQUAN WANG ${ }^{1}$, YINGBING ZHANG ${ }^{1}$, XU LIU $^{2}$, JIZHAO WANG $^{2}$, \\ $\mathrm{BIN} \mathrm{LI}^{3}$, YONGKANG LIU ${ }^{3}$ and JIANSHENG WANG ${ }^{2}$
}

\begin{abstract}
Departments of ${ }^{1}$ Radiation Oncology and ${ }^{2}$ Thoracic Surgery, The First Affiliated Hospital, Xi'an Jiaotong University, Xi'an, Shaanxi 710061; ${ }^{3}$ Key Laboratory of Resource Biology and Biotechnology in Western China, Northwest University, Xi'an, Shaanxi 710069, P.R. China
\end{abstract}

Received August 7, 2018; Accepted June 18, 2019

DOI: $10.3892 / \mathrm{ijmm} .2019 .4268$

\begin{abstract}
Lung cancer is one of the leading causes of cancer-associated mortality in China and globally. Gemcitabine (GEM), as a first-line therapeutic drug, has been used to treat lung cancer, but GEM resistance poses a major limitation on the efficacy of GEM chemotherapy. Alantolactone (ALT), a sesquiterpene lactone compound isolated from Inula helenium, has been identified to exert anticancer activity in various types of cancer, including breast, pancreatic, lung squamous and colorectal cancer. However, the underlying mechanisms of the anticancer activity of ALT in lung cancer remain to be fully elucidated. The present study aimed to determine whether ALT enhances the anticancer efficacy of GEM in lung cancer cells and investigated the underlying mechanisms. The cell viability was assessed with a Cell Counting Kit-8 assay. The cell cycle, apoptosis and the level of reactive oxygen species (ROS) were assessed by flow cytometry, and the expression of cell cycle-associated and apoptosis-associated proteins were determined by western blot analysis. The results demonstrated that ALT inhibited cell growth and induced S-phase arrest and cell apoptosis in A549 and NCI-H520 cells. Furthermore, ALT increased the level of ROS, inhibited the Akt/glycogen synthase kinase (GSK) $3 \beta$ pathway and induced endoplasmic reticulum (ER) stress in A549 and NCI-H520 cells. Additionally, ALT treatment sensitized lung cancer cells to GEM. Analysis of the molecular mechanisms further revealed that ALT enhanced the anticancer effects of GEM via ROS-mediated activation
\end{abstract}

Correspondence to: Dr Jiansheng Wang, Department of Thoracic Surgery, The First Affiliated Hospital, Xi'an Jiaotong University, 277 Yanta West Road, Xi'an, Shaanxi 710061, P.R. China

E-mail: wangjsh@mail.xjtu.edu.cn

Key words: lung cancer cells, apoptosis, cell cycle arrest, endoplasmic reticulum stress, Akt, glycogen synthase kinase $3 \beta$, alantolactone, gemcitabine resistance of the Akt/GSK3 $\beta$ and ER stress pathways. In conclusion, combined treatment with ALT and GEM may have potential as a clinical strategy for lung cancer treatment.

\section{Introduction}

Lung cancer is one of the leading causes of cancer-associated mortality in China and globally (1). Lung cancer can be classified into non-small cell lung cancer (NSCLC), accounting for $\sim 80-85 \%$ of cases, and small cell lung cancer (SCLC), accounting for $\sim 10-15 \%$ of cases (2-4). At present, the standard treatment strategy for lung cancer includes surgical resection, chemotherapy and radiation therapy (5). Furthermore, chemotherapy remains one of the commonly used therapeutic regimens for advanced lung cancer (6). Gemcitabine (GEM) as a first-line therapeutic drug has been used to treat lung cancer, but GEM resistance poses a major limitation to the efficacy of GEM chemotherapy (7). Therefore, it is important to develop novel agents and therapeutic strategies to overcome resistance.

Numerous recent studies focused on natural products, which may be sources of novel natural antitumor agents (8-10). Furthermore, a number of antitumor drugs, including paclitaxel, docetaxel and vinorelbine, have been developed from natural products and are successfully used to treat cancer (11). It has been reported that certain natural products exert anticancer effects through a number of mechanisms of action, including the inhibition of phosphoinositide-3 kinase (PI3K)/Akt, induction of endoplasmic reticulum (ER) stress and the generation of reactive oxygen species (ROS) in various cancer types, including colorectal, lung and prostate cancer (12-14). Additionally, Wang et al (15) reported that licoricidin enhances GEM-induced cytotoxicity by suppressing the Akt pathways in osteosarcoma cells. Cheng et al (16) reported that resveratrol enhances the sensitivity of pancreatic cancer cells to GEM via the accumulation of ROS.

Alantolactone (ALT), a sesquiterpene lactone compound isolated from Inula helenium (Fig. 1A), has been reported to exert anticancer effects against various types of cancer. ALT was demonstrated to promote apoptosis in colorectal cancer cells via ROS overproduction (17). ALT may induce apoptosis 
of human cervical cancer cells via ROS generation (18). In MDA-MB-231 breast cancer cells, ALT induces apoptosis via the ROS-mediated mitochondrion-dependent pathway (19). Furthermore, ALT may trigger apoptosis and induce cell cycle arrest in the $G_{1} / G_{0}$ phase in SK-MES-1 lung squamous cancer cells (20). Additionally, Maryam et al (21) reported that ALT enhanced the chemosensitivity of A549 cells to doxorubicin via ROS-mediated inhibition of signal transducer and activator of transcription 3 activation.

In the present study, it was first examined whether ALT may enhance the sensitivity of human lung cancer cells to GEM and then the underlying mechanisms were investigated. The results provide evidence that ALT in combination with GEM may be a promising strategy for treating lung cancer.

\section{Materials and methods}

Reagents and antibodies. ALT and N-acetyl-L-cysteine (NAC; a ROS scavenger) were purchased from Sigma-Aldrich (Merck KGaA, Darmstadt, Germany). Dulbecco's modified Eagle's medium (DMEM) and fetal bovine serum (FBS) were from Gibco (Thermo Fisher Scientific, Inc., Waltham, MA, USA). Anti-CCAAT-enhancer-binding protein homologous protein (CHOP) monoclonal antibody (cat. no. 5554), anti-phosphorylated (p) eukaryotic initiation factor $2 \alpha$ [p-eIF2 $\alpha$ (Ser51); cat. no. 9721], anti-eIF2 $\alpha$ (cat. no. 9722), anti-cyclin A2 (cat. no. 4656), anti-p-Akt (cat. no. 4058), anti-Akt (cat. no. 9272), anti-p-glycogen synthase kinase $3 \beta$ [p-GSK3 $\beta$ (Ser9); cat. no. 5558], anti-GSK3 $\beta$ (cat. no. 12456), anti- $\beta$-actin (cat. no. 4967) and anti-caspase-3 (cat. no. 9662) were purchased from Cell Signal Technology, Inc. (Danvers, MA, USA). Anti-p21 (cat. no. 195720) was purchased from R\&D Systems, Inc. (Minneapolis, MN, USA). Horseradish peroxidase (HRP)-conjugated anti-mouse IgG (cat. no. 7076) and HRP-conjugated anti-rabbit IgG (cat. no. 7074) were purchased from Cell Signal Technology Inc.. Tunicamycin (TM; an ER stress agonist) was purchased from Merck KGaA. LY294002 (a PI3K inhibitor) was purchased from MedChem Express (Monmouth Junction, NJ, USA).

Cell culture. The A549 and NCI-H520 human lung carcinoma cells lines were provided by the Cell Bank of the Shanghai Institute of Biochemistry and Cell Biology (Shanghai, China). The cells were cultured in DMEM supplemented with $10 \%$ FBS, $100 \mathrm{U} / \mathrm{ml}$ penicillin and $100 \mu \mathrm{g} / \mathrm{ml}$ streptomycin at $37^{\circ} \mathrm{C}$ in an atmosphere containing $5 \% \mathrm{CO}_{2}$.

Cell viability assay. The A549 and NCI-H520 cells were seeded in 96 -well plates at a density of $1.5 \times 10^{4}$ cells/well and incubated for $24 \mathrm{~h}$ at $37^{\circ} \mathrm{C}$. Cell viability was detected by using a Cell Counting Kit-8 (CCK-8; Dojindo Molecular Technologies, Inc., Kumamoto, Japan), following the manufacturer's protocol. In brief, the A549 cells were treated with 0,1 , $2,4,6,8$ and $10 \mu \mathrm{M}$ ALT or $0,12.5,25,50,100$, and $200 \mu \mathrm{M}$ GEM for $24 \mathrm{~h}$ at $37^{\circ} \mathrm{C}$. The NCI-H520 cells were treated with $0,20,30,40,50,60,70$ and $80 \mu \mathrm{M}$ ALT or $0,12.5,25,50,100$ and $200 \mu \mathrm{M} \mathrm{GEM}$ for $24 \mathrm{~h}$ at $37^{\circ} \mathrm{C}$. Furthermore, the A549 cells were treated with or without $4 \mu \mathrm{M}$ ALT and $25 \mu \mathrm{M}$ GEM for $24 \mathrm{~h}$ at $37^{\circ} \mathrm{C}$. The NCI-H520 cells were treated with or without $40 \mu \mathrm{M}$ ALT and $25 \mu \mathrm{M}$ GEM for $24 \mathrm{~h}$ at $37^{\circ} \mathrm{C}$. In addition,
LY294002 $(4 \mu \mathrm{m})$ was added $1 \mathrm{~h}$ prior to certain treatments, and then the A549 and NCI-H520 cells were treated with or without GEM $(25 \mu \mathrm{m})$ for $24 \mathrm{~h}$ at $37^{\circ} \mathrm{C}$. A total of $10 \mu \mathrm{l} \mathrm{CCK}-8$ solution was added to each well during the last $4 \mathrm{~h}$ of incubation at $37^{\circ} \mathrm{C}$. The absorbance at $450 \mathrm{~nm}$ was detected using an ELISA reader (Tecan Group Ltd., Mannedorf, Switzerland). The experiments were performed in triplicate. Additionally, morphological changes in A549 and NCI-H520 cells treated with different concentrations of ALT and GEM for $24 \mathrm{~h}$ were monitored using an inverted light microscope (magnification, $\mathrm{x} 200$ ).

Cell cycle analysis. The A549 and NCI-H520 cells were seeded in 6-well plates at a density of $2.5 \times 10^{5}$ cells/well for $24 \mathrm{~h}$ at $37^{\circ} \mathrm{C}$. The cell cycle distribution was analyzed with a Cell Cycle Detection kit (cat. no. KGA512; Nanjing KeyGen Biotech Co., Ltd., Nanjing, China) and a FACScalibur flow cytometer (BD Biosciences, San Jose, CA, USA), according to the manufacturer's protocols. In brief, the A549 cells were treated with or without $4 \mu \mathrm{M}$ ALT and $25 \mu \mathrm{M}$ GEM for $24 \mathrm{~h}$ at $37^{\circ} \mathrm{C}$. The NCI-H520 cells were treated with or without $40 \mu \mathrm{M}$ ALT and $25 \mu \mathrm{M}$ GEM for $24 \mathrm{~h}$ at $37^{\circ} \mathrm{C}$. Cells were trypsinized and single-cell suspensions were fixed with $75 \%$ ethanol overnight at $4^{\circ} \mathrm{C}$. Propidium iodide (PI) was used to stain the DNA in the samples for $15 \mathrm{~min}$ at $25^{\circ} \mathrm{C}$, and flow cytometry was used to detect cell cycle distribution. The results were analyzed with ModFit LT 3.0 (Verity Software House, Inc., Topsham, ME, USA). The experiments were performed in triplicate.

Assay of cell apoptosis. The A549 and NCI-H520 cells were seeded in 6-well plates at a density of $2.5 \times 10^{5}$ cells/well for $24 \mathrm{~h}$ at $37^{\circ} \mathrm{C}$. Cell apoptosis was assessed using an Annexin V-fluorescein isothiocyanate (FITC) Apoptosis Detection kit (cat. no. KGA104; Nanjing KeyGen Biotech Co., Ltd.), according to the manufacturer's protocol. In brief, the A549 and NCI-H520 cells were pre-treated with NAC $(8 \mathrm{mM})$ for $2 \mathrm{~h}$ at $37^{\circ} \mathrm{C}$. The A549 cells were then treated with or without $4 \mu \mathrm{M}$ ALT and $25 \mu \mathrm{M}$ GEM for $24 \mathrm{~h}$ at $37^{\circ} \mathrm{C}$. The NCI-H520 cells were treated with or without $40 \mu \mathrm{M}$ ALT and $25 \mu \mathrm{M}$ GEM for $24 \mathrm{~h}$ at $37^{\circ} \mathrm{C}$. Annexin V-FITC and PI were used to stain the cells for $15 \mathrm{~min}$ at $37^{\circ} \mathrm{C}$ in dark room. The apoptotic cells were then detected with a FACScalibur flow cytometer and analyzed by FlowJo 7.6 software (FlowJo LLC, Ashland, OR, USA). The experiments were performed in triplicate.

Measurement of ROS generation. Intracellular ROS production was measured with a ROS assay kit (Nanjing Jiancheng Bioengineering Institute, Nanjing, China) using flow cytometry, according to the manufacturer's protocol. In brief, the A549 cells were treated with or without $4 \mu \mathrm{M}$ ALT and $25 \mu \mathrm{M}$ GEM for $12 \mathrm{~h}$ at $37^{\circ} \mathrm{C}$. The NCI-H520 cells were treated with or without $40 \mu \mathrm{M}$ ALT and $25 \mu \mathrm{M}$ GEM for $12 \mathrm{~h}$ at $37^{\circ} \mathrm{C}$. The cells were then incubated with $10 \mu \mathrm{M}$ 2',7'-dichlorodihydrofluorescein diacetate for $15 \mathrm{~min}$ at $37^{\circ} \mathrm{C}$ in the dark. The cells were analyzed using a FACScalibur flow cytometer. The results were analyzed with FlowJo 7.6 software and the experiments were performed in triplicate.

Western blot analysis. The A549 and NCI-H520 cells were seeded in $35-\mathrm{mm}$ cell culture dishes at a density of 
<smiles>C=C1C(=O)O[C@@H]2C(C)C3(C)CCCC(C)C3=C[C@@H]12</smiles>
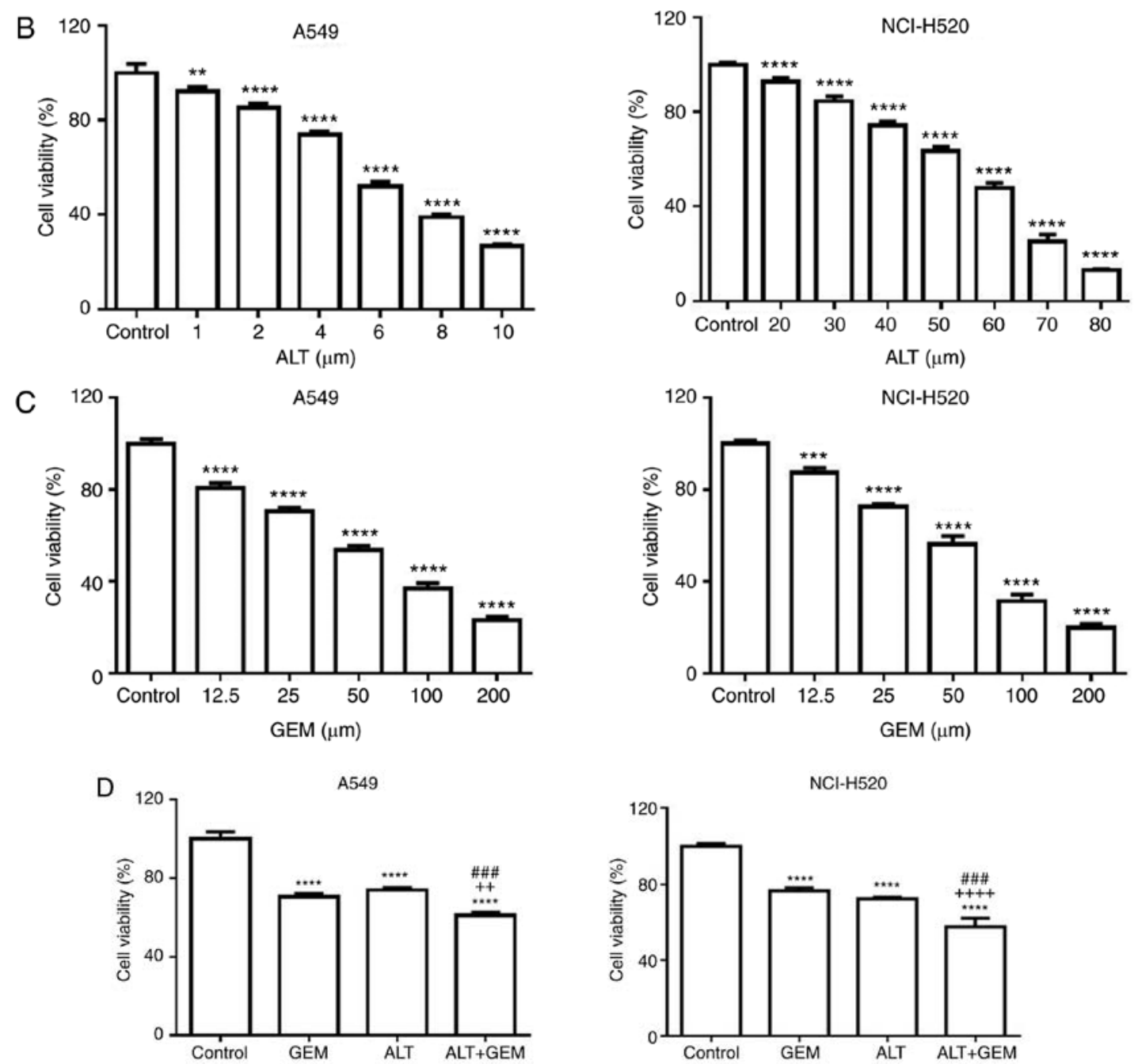

E

Control

GEM
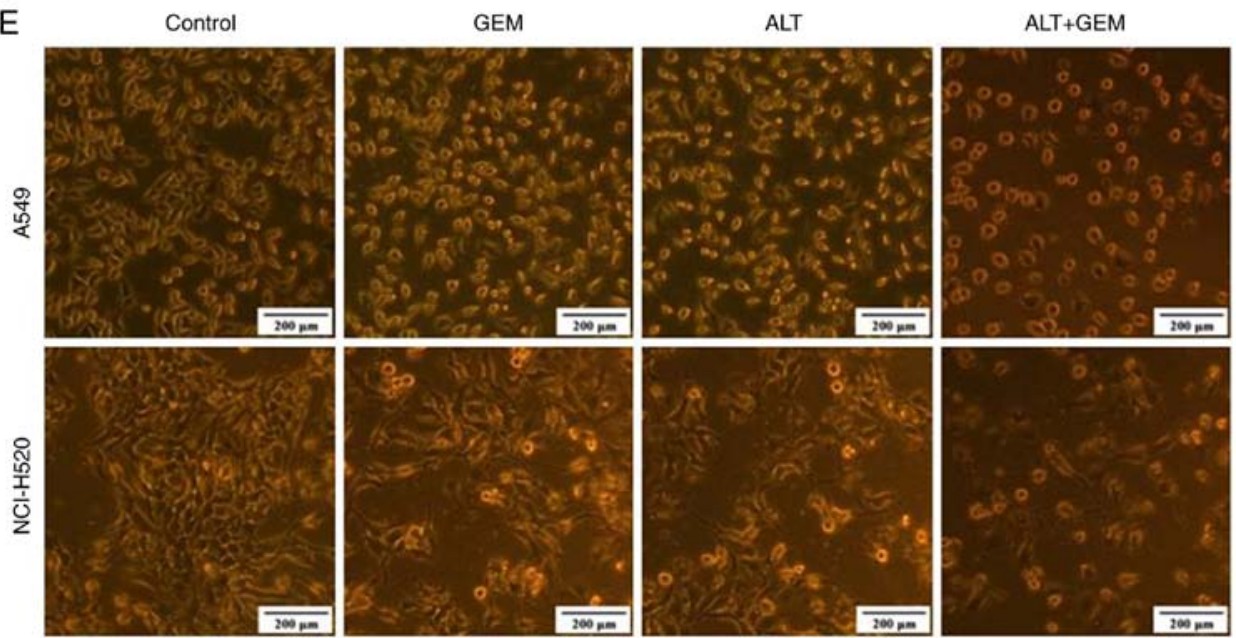

Figure 1. Effects of ALT and/or GEM treatment on the proliferation of lung cancer cells. (A) Chemical structure of ALT. (B) A549 and NCI-H520 cells were treated with various concentrations of ALT. (C) A549 and NCI-H520 cells were treated with various concentrations of GEM. (D) A549 cells were treated with ALT $(4 \mu \mathrm{m})$ and/or GEM $(25 \mu \mathrm{m})$. NCI-H520 cells were treated with ALT $(40 \mu \mathrm{m})$ and/or GEM $(25 \mu \mathrm{m})$. After $24 \mathrm{~h}$ of incubation, the cell viability was determined with a Cell Counting Kit-8 assay. (E) A549 cells were treated with ALT ( $4 \mu \mathrm{m})$ and/or GEM ( $25 \mu \mathrm{m})$. NCI-H520 cells were treated with ALT $(40 \mu \mathrm{m})$ and/or GEM $(25 \mu \mathrm{m})$. After $24 \mathrm{~h}$ of incubation, morphological changes were visualized under an inverted light microscope. Magnification, $\mathrm{x} 200$. Values are expressed as the mean \pm standard deviation from three independent experiments. ${ }^{* *} \mathrm{P}<0.01,{ }^{* * *} \mathrm{P}<0.001$ and ${ }^{* * * * *} \mathrm{P}<0.0001 \mathrm{vs}$. control. ${ }^{++} \mathrm{P}<0.01$ and ${ }^{++++} \mathrm{P}<0.0001$ vs. GEM. ${ }^{\# \# \#} \mathrm{P}<0.001$ vs. ALT. GEM, gemcitabine; ALT, alantolactone. 
$2.5 \times 10^{5}$ cells/well for $24 \mathrm{~h}$ at $37^{\circ} \mathrm{C}$. The $\mathrm{A} 549$ cells were treated with or without $4 \mu \mathrm{M}$ ALT and $25 \mu \mathrm{M}$ GEM for $12 \mathrm{~h}$ at $37^{\circ} \mathrm{C}$. The NCI-H520 cells were treated with or without $40 \mu \mathrm{M}$ ALT and $25 \mu \mathrm{M}$ GEM for $12 \mathrm{~h}$ at $37^{\circ} \mathrm{C}$. Furthermore, the A549 cells were treated with ALT $(4 \mu \mathrm{m})$ and NCI-H520 cells were treated with ALT $(40 \mu \mathrm{m})$ for 3,6 or $12 \mathrm{~h}$. In addition, the A549 and NCI-H520 cells were treated with LY294002 (4 $\mu \mathrm{m})$ for $12 \mathrm{~h}$. In a separate experiment, the A549 and NCI-H520 cells were pre-treated with NAC $(8 \mathrm{mM})$ for $2 \mathrm{~h}$ at $37^{\circ} \mathrm{C}$, followed by treatment with or without $4 \mu \mathrm{M}$ ALT and $25 \mu \mathrm{M}$ GEM for $12 \mathrm{~h}$ at $37^{\circ} \mathrm{C}$ for the $\mathrm{A} 549$ cells, and treatment with or without $40 \mu \mathrm{M}$ ALT and $25 \mu \mathrm{M}$ GEM for $12 \mathrm{~h}$ at $37^{\circ} \mathrm{C}$ for the NCI-H520 cells.

Following the different treatments, the A549 and NCI-H520 cells were harvested and lysed in RIPA buffer (Beyotime Institute of Biotechnology, Haimen, China) with protease inhibitors (Sigma Aldrich, St. Louis, MO, USA) on ice for $30 \mathrm{~min}$ and then centrifuged at $12,000 \mathrm{x} \mathrm{g}$ for $10 \mathrm{~min}$ at $4^{\circ} \mathrm{C}$, as described previously (22). The proteins were then quantified with a Bicinchoninic Acid Protein assay kit (Thermo Fisher Scientific, Inc.). Equal amounts of protein samples $(40 \mu \mathrm{g}$ protein/well) were separated by $10-15 \%$ SDS-PAGE, according to molecular weight of protein. Akt and p-Akt were separated by $10 \%$ SDS-PAGE. GSK3 $\beta$, p-GSK3 $\beta$, eIF $2 \alpha$, p-eIF $2 \alpha$, cyclin A 2 and $\beta$-actin were separated by $12 \%$ SDS-PAGE. CHOP, p21 and caspase-3 were separated by $15 \%$ SDS-PAGE. Subsequently, the protein samples were transferred onto nitrocellulose membranes (Pall Life Sciences, Port Washington, NY, USA). The membranes were blocked with $5 \%$ non-fat milk for $2 \mathrm{~h}$ at $25^{\circ} \mathrm{C}$, followed by incubation with anti-CHOP (1:2,000 dilution), anti-p-eIF2 $\alpha$ (Ser51) (1:3,000 dilution), anti-eIF2 $\alpha$ (1:4,000 dilution), anti-cyclin A2 (1:1,000 dilution), anti-p-Akt (1:2,000 dilution), anti-Akt (1:3,000 dilution), anti-p-GSK3 $\beta$ (Ser9) (1:5,000 dilution), anti-GSK3 $\beta$ (1:5,000 dilution), anti- $\beta$-actin (1:6,000 dilution), anti-caspase-3 (1:1,000 dilution) and anti-p21 (1:1,000 dilution) antibodies overnight at $4^{\circ} \mathrm{C}$. The membranes were incubated with a HRP-conjugated secondary antibody (1:20,000 dilution) at room temperature for $2 \mathrm{~h}$. The reaction was visualized using SuperSignal West Pico chemiluminescent Substrate (Pierce; Thermo Fisher Scientific, Inc.), followed by exposure to Kodak X-ray film (Kodak, Rochester, NY, USA).

Statistical analysis. Values are expressed as the mean \pm standard deviation. Data were analyzed using GraphPad Prism 6.0 (GraphPad Software Inc., La Jolla, CA, USA). Differences between groups were determined by one-way analysis of variance, followed by Dunnett's post-hoc test. $\mathrm{P}<0.05$ was considered to indicate a statistically significant difference.

\section{Results}

ALT enhances GEM-induced cytotoxicity in A549 and NCI-H520 cells. To assess whether ALT synergizes with GEM to inhibit cell proliferation, A549 and NCI-H520 cells were first treated with increasing doses of ALT and GEM for $24 \mathrm{~h}$, and the cell viability was assessed with a CCK-8 assay. As depicted in Fig. 1B and C, ALT or GEM significantly decreased the growth of A549 and NCI-H520 cells in a dose-dependent manner. It was notable that A549 cells [half maximal inhibitory concentration $\left(\mathrm{IC}_{50}\right)=6.63 \pm 1.10 \mu \mathrm{M}$ ] were more sensitive to ALT, compared with NCI-H520 cells $\left(\mathrm{IC}_{50}=59.91 \pm 1.16 \mu \mathrm{M}\right)$, while the sensitivity of A549 cells $\left(\mathrm{IC}_{50}=8.39 \pm 1.02 \mu \mathrm{M}\right)$ and NCI-H520 $\left(\mathrm{IC}_{50}=58.76 \pm 1.06 \mu \mathrm{M}\right)$ to GEM was similar. Based on the results, $4 \mu \mathrm{M}$ ALT and $25 \mu \mathrm{M}$ GEM were used in A549 cells for the subsequent experiments. NCI-H520 cells were treated with $40 \mu \mathrm{M}$ ALT and $25 \mu \mathrm{M}$ GEM for the subsequent experiments. The cell viability of A549 and NCI-H520 cells was investigated with a CCK-8 assay. Furthermore, the results indicated that the viability of A549 and NCI-H520 cells was significantly decreased by combined treatment, compared with ALT or GEM treatment alone (Fig. 1D). Morphological observation also indicated that combined treatment notably decreased the percentage of surviving cells, compared with those subjected to ALT or GEM treatment alone (Fig. 1E). These results indicated that ALT significantly enhances the synergism of GEM by inhibiting the cell proliferation of A549 and NCI-H520 cells.

ALT enhances GEM-induced cell cycle arrest in A549 and NCI-H52O cells. Numerous studies demonstrated that cell cycle arrest induced by anticancer drugs has an important role in cell growth inhibition (23-25). To verify whether cell cycle arrest is involved in the GEM sensitization effect, the impact of ALT and GEM on the cell cycle distribution was determined in A549 and NCI-H520 cells with flow cytometry. The cell cycle assay demonstrated that ALT, GEM and their co-treatment significantly induced S-phase arrest, compared with the control group (Fig. 2A and B). The combination treatment with ALT and GEM significantly increased the $\mathrm{S}$-phase arrest, compared with that caused by ALT or GEM treatment alone (Fig. 2A and B). Furthermore, western blot analysis was performed to examine the expression levels of S-phase-associated proteins in A549 and NCI-H520 cells. As depicted in Fig. 2C, ALT, GEM and co-treatment with ALT and GEM caused a notable upregulation of the expression levels of p21 but a downregulation of cyclin A2, compared with that in the control group. Compared with that in the mono-treatment groups, the levels of cyclin A2 in the co-treatment group were decreased, while the levels of p21 were increased in A549 and NCI-H520 cells. These results indicated that S-phase arrest contributes to the synergistic effect induced by ALT on the growth inhibition properties of GEM in A549 and NCI-H520 cells.

ALT enhances GEM-induced apoptosis in A549 and NCI-H520 cells. To further investigate the synergistic effect induced by ALT on the growth inhibition by GEM, the apoptosis of A549 and NCI-H520 cells treated with ALT and GEM was examined with flow cytometry. As depicted in Fig. 3A and B, ALT, GEM and their combination significantly increased the apoptotic rate of A549 and NCI-H520 cells. Compared with that in the mono-treatment groups, the apoptotic rate was significantly increased in the combined group (Fig. 3A and B). The levels of the apoptosis-associated protein caspase-3 in A549 and NCI-H520 cells were also examined with western blot analysis. It was observed that ALT, GEM and their combination notably increased the expression levels of activation of caspase-3. Compared with those in the mono-treatment groups, the levels of activation of caspase- 3 were notably increased in the combined treatment group 
A

Control
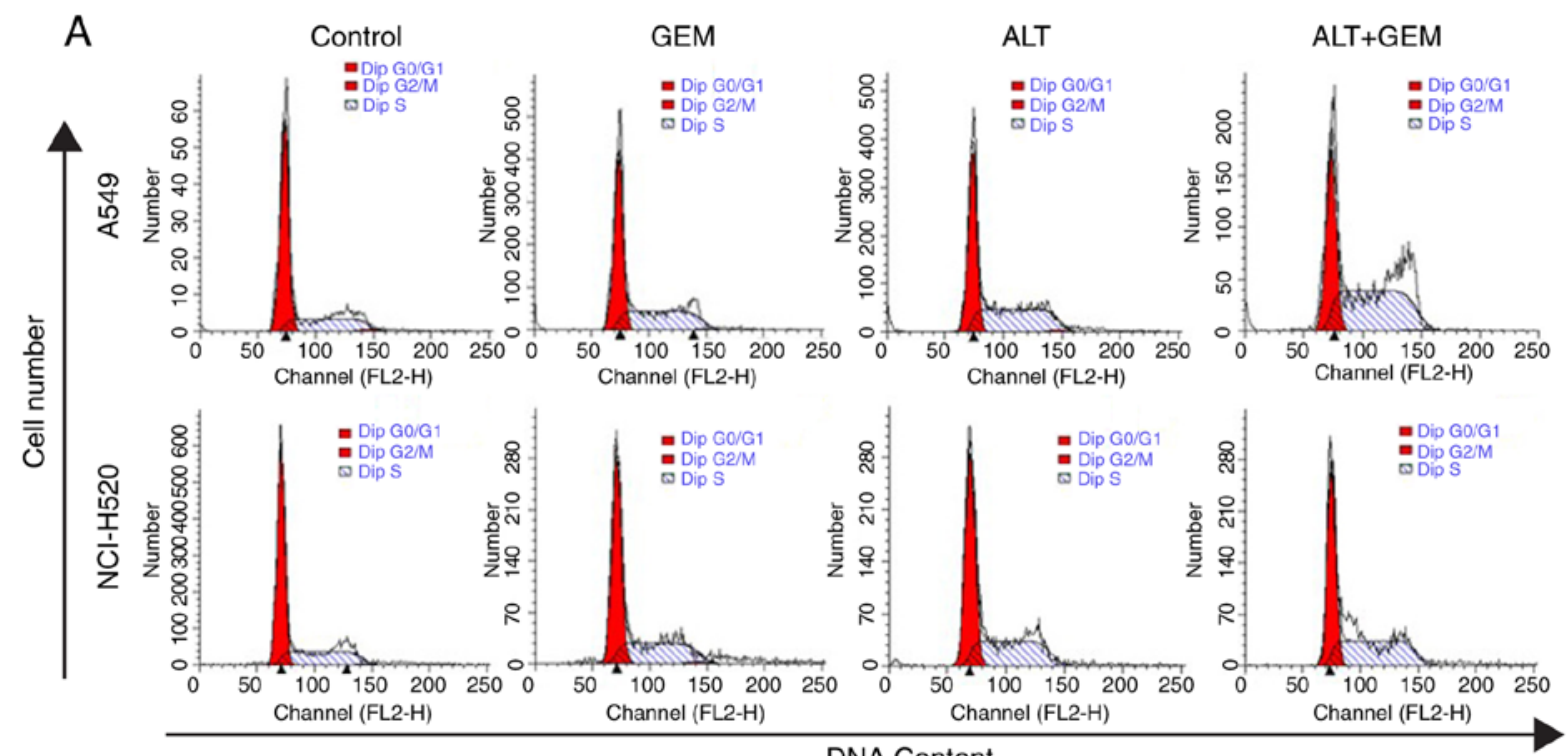

DNA Content
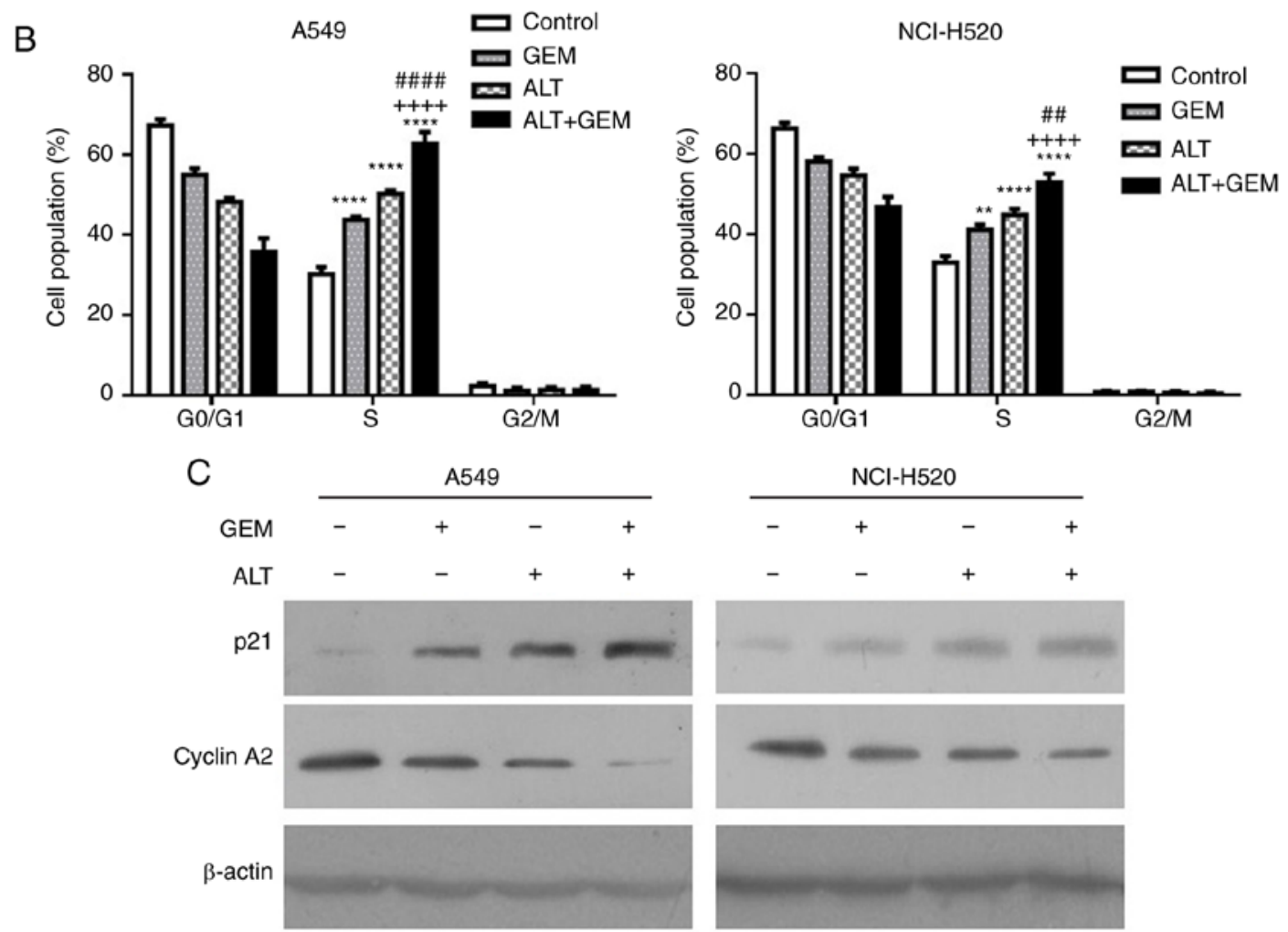

Figure 2. Effects of ALT and/or GEM treatment on the cell cycle in lung cancer cells. A549 cells were treated with ALT (4 $\mu \mathrm{m})$ and/or GEM (25 $\mu \mathrm{m})$. NCI-H520 cells were treated with ALT $(40 \mu \mathrm{m})$ and/or GEM $(25 \mu \mathrm{m})$. (A) After $24 \mathrm{~h}$ of incubation, the cell cycle was analyzed by flow cytometry. (B) Bar graphs present the quantification of the cell cycle populations. (C) After $12 \mathrm{~h}$ of incubation, cyclin A2 and p21 were determined by western blot analysis. $\beta$-actin served as a loading control. Values are expressed as the mean \pm standard deviation from three independent experiments. ${ }^{* * *} \mathrm{P}<0.01$ and ${ }^{* * * * *} \mathrm{P}<0.0001$ vs. control. ${ }^{++++} \mathrm{P}<0.0001$ vs. GEM. ${ }^{\# \#} \mathrm{P}<0.01$ and ${ }^{\# \# \#+} \mathrm{P}<0.0001$ vs. ALT. GEM, gemcitabine; ALT, alantolactone.

(Fig. 3C). These results demonstrated that ALT significantly enhances the sensitivity to GEM by inducing cell apoptosis in A549 and NCI-H520 cells.

ALT sensitizes GEM-mediated cell apoptosis via ROS production in $\mathrm{A} 549$ and NCI-H52O cells. Previous studies indicated that ROS has a critical role in anticancer drug-mediated apoptosis $(26,27)$. Therefore, the effects of ALT and GEM on ROS production in A549 and NCI-H520 cells were assessed by flow cytometry. As depicted in Fig. 4A and B, ALT, GEM and their combination significantly increased ROS accumulation in A549 and NCI-H520 cells. Compared with the mono-treatments, the co-treatment significantly enhanced ROS accumulation. To further investigate whether ROS generation contributes to ALT- and GEM-mediated apoptosis, A549 and NCI-H520 cells were pre-treated with NAC (ROS scavenger) prior to treating the cells with ALT and GEM, and apoptosis was then detected by flow cytometry. The results indicated 
A

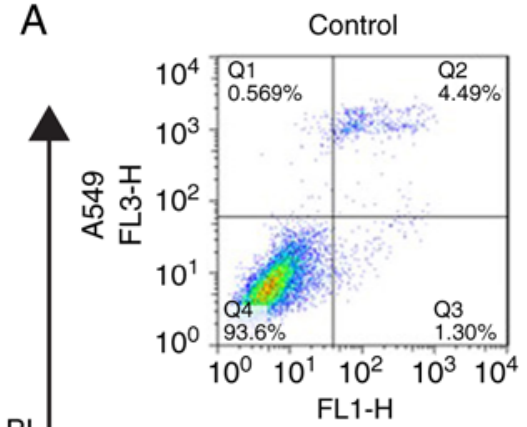

$\mathrm{PI}$

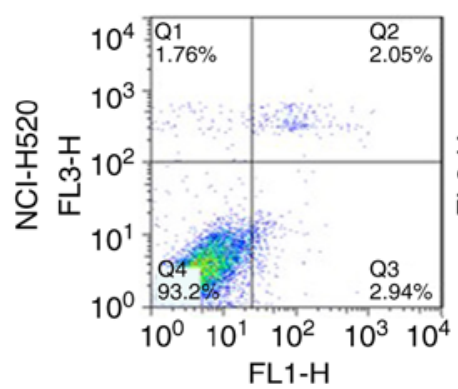

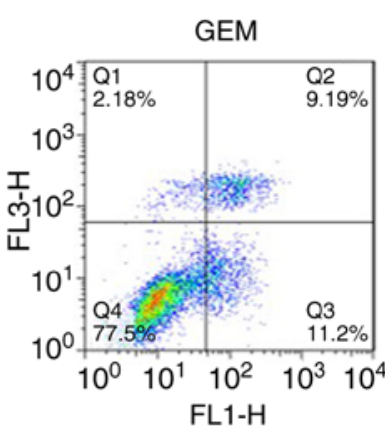
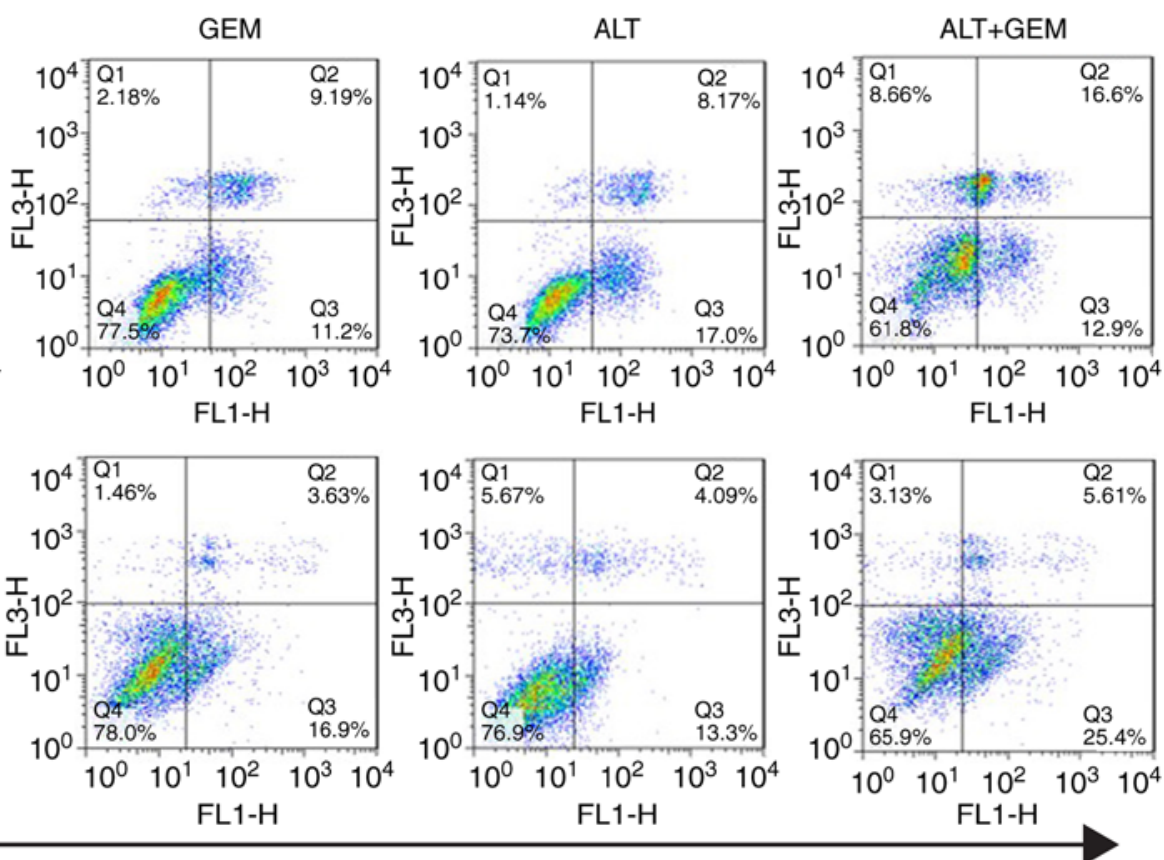

B

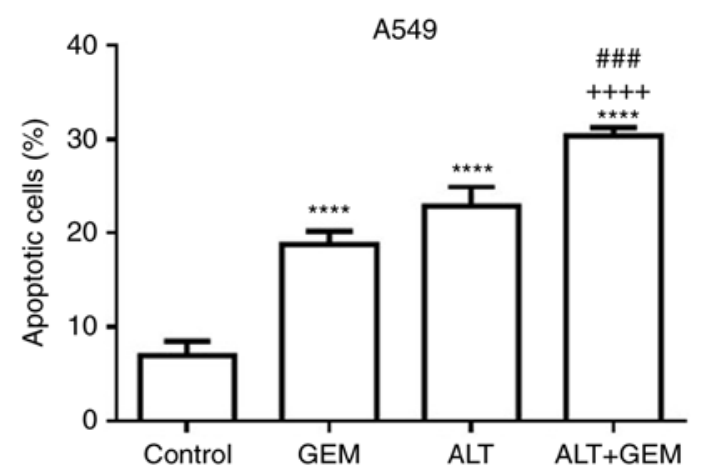

Annexin V

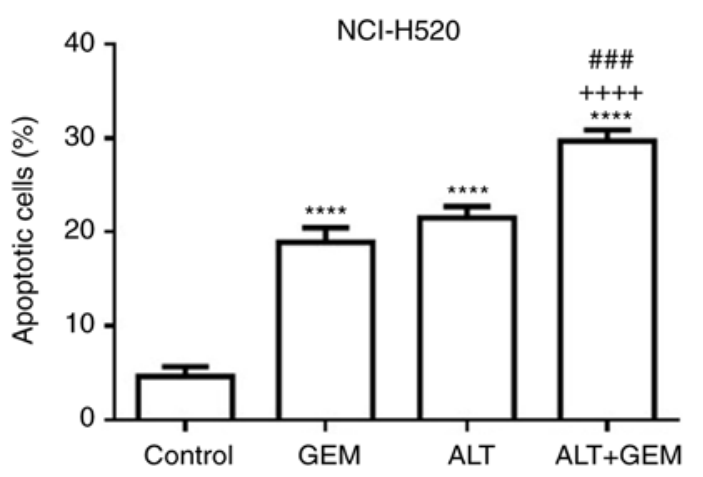

C
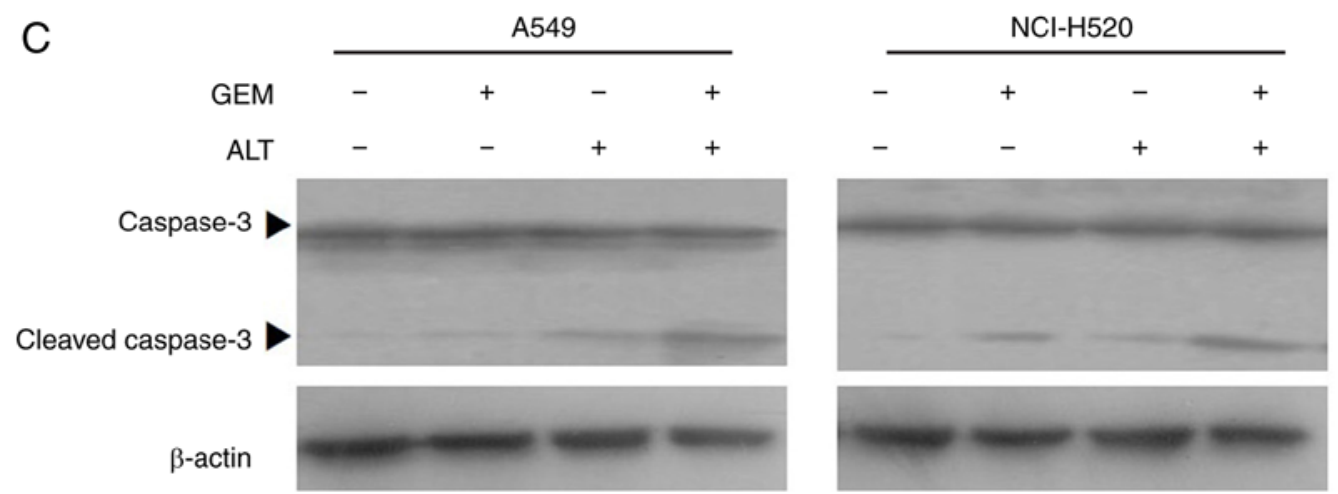

Figure 3. Effects of ALT and/or GEM on apoptosis of lung cancer cells. A549 cells were treated with ALT (4 $\mu \mathrm{m})$ and/or GEM (25 $\mu \mathrm{m})$. NCI-H520 cells were treated with ALT $(40 \mu \mathrm{m})$ and/or GEM $(25 \mu \mathrm{m})$. (A) After $24 \mathrm{~h}$ of incubation, cell apoptosis was examined by flow cytometry. (B) Bar graphs present the quantification of the cell apoptosis analysis. (C) After $12 \mathrm{~h}$ of incubation, the levels of caspase- 3 were determined by western blot analysis. $\beta$-actin served as a loading control. Values are expressed as the mean \pm standard deviation from three independent experiments. ${ }^{* * * *} \mathrm{P}<0.0001$ vs. control. ${ }^{+++} \mathrm{P}<0.0001$ vs. GEM.

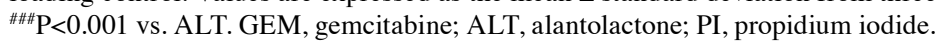

that pre-treatment with NAC significantly decreased ALTand GEM-induced apoptosis in A549 and NCI-H520 cells (Fig. 4C and D). Additionally, western blot analysis revealed that pre-treatment with NAC notably attenuated the increases in the levels of activation of caspase- 3 induced by ALT and GEM treatment in A549 and NCI-H520 cells (Fig. 4E). Thus, these results demonstrated that ALT enhances GEM-mediated apoptosis via increasing the intracellular ROS production in A549 and NCI-H520 cells.

ALT sensitizes A549 and NCI-H520 cells to GEM-mediated cell apoptosis via induction of ROS-mediated ER stress. It has been reported that ROS generation induces cell apoptosis through activating ER stress pathways in a variety of cancer 
A

Control
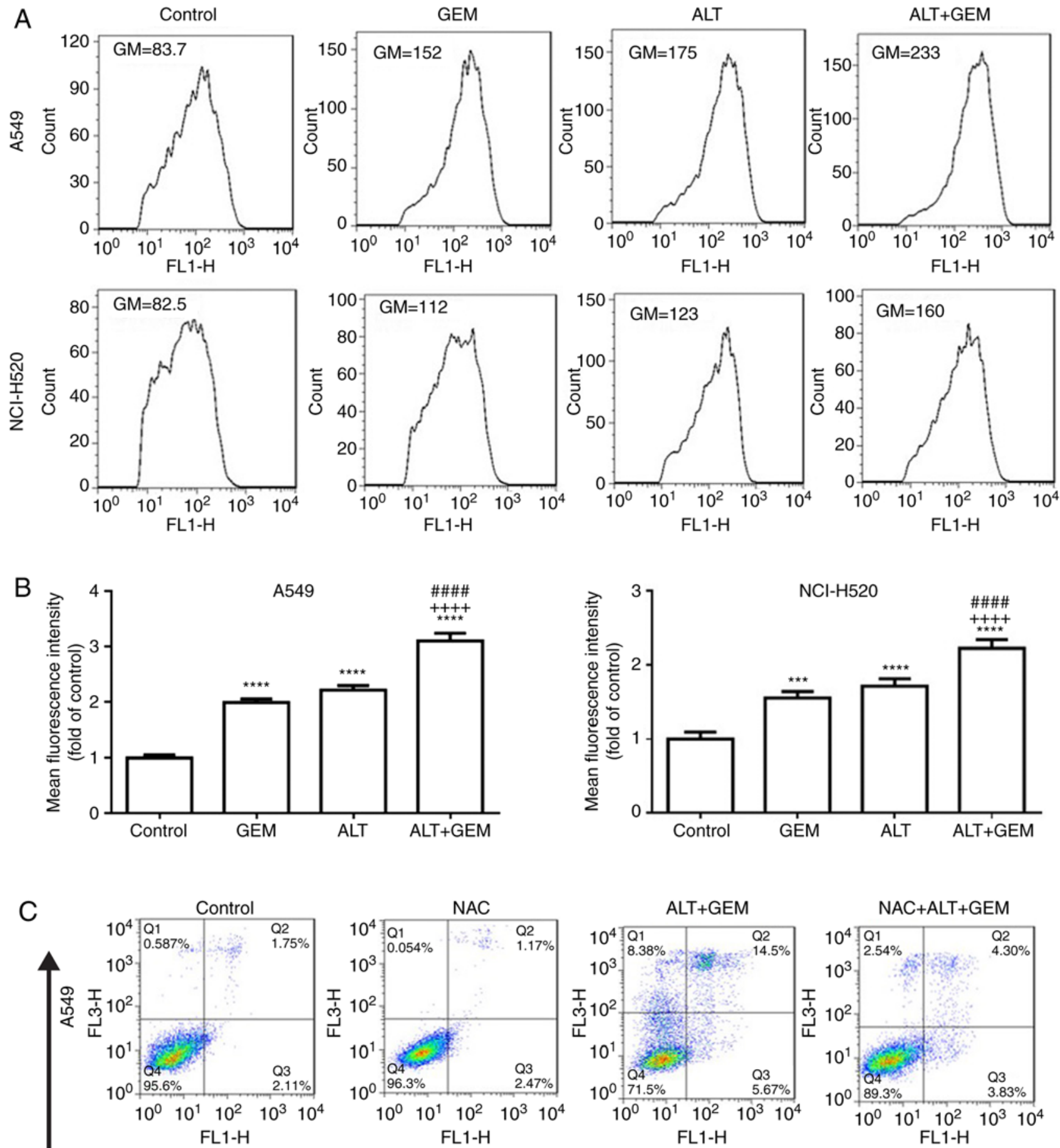

$\mathrm{Pl}$
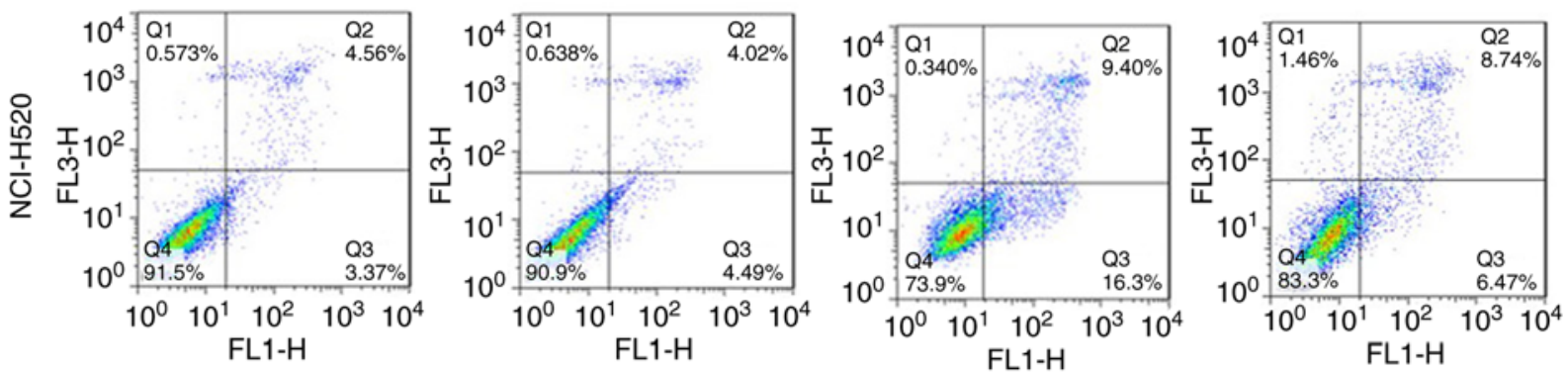

Annexin V

Figure 4. Effects of ALT and/or GEM on intracellular ROS generation in lung cancer cells. (A) A549 cells were treated with ALT (4 $\mu \mathrm{m})$ and/or GEM ( $25 \mu \mathrm{m})$. NCI-H520 cells were treated with ALT $(40 \mu \mathrm{m})$ and/or GEM $(25 \mu \mathrm{m})$. After $12 \mathrm{~h}$ of incubation, the levels of ROS were examined by flow cytometry. (B) Bar graphs present the quantification of the levels of ROS. A549 and NCI-H520 cells were pre-treated with NAC ( $8 \mathrm{mM})$ for $2 \mathrm{~h}$, followed by treatment with ALT $(4 \mu \mathrm{m})$ and/or GEM $(25 \mu \mathrm{m})$ in A549 cells and treatment with ALT $(40 \mu \mathrm{m})$ and/or GEM $(25 \mu \mathrm{m})$ in NCI-H520 cells for $24 \mathrm{~h}$. (C) Cell apoptosis was examined by flow cytometry. 

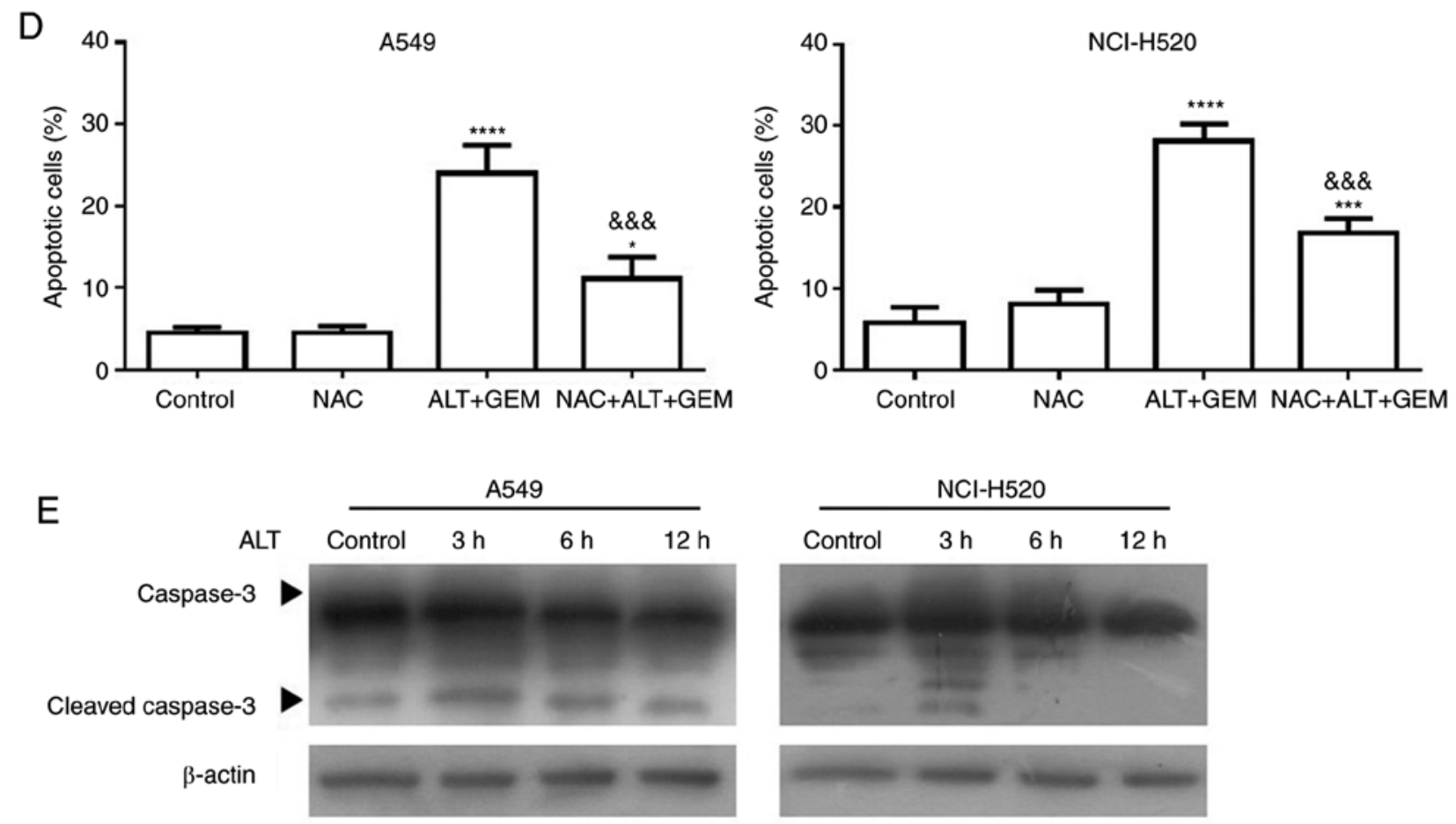

Figure 4. Continued. Effects of ALT and/or GEM on intracellular ROS generation in lung cancer cells. (D) Bar graphs present the quantification of the cell apoptosis. (E) After $12 \mathrm{~h}$ of incubation, the levels of caspase-3 were determined by western blot analysis. $\beta$-actin served as a loading control. Values are expressed as the mean \pm standard deviation from three independent experiments. ${ }^{*} \mathrm{P}<0.05,{ }^{* * *} \mathrm{P}<0.001$ and ${ }^{* * * * *} \mathrm{P}<0.0001$ vs. control. ${ }^{++++} \mathrm{P}<0.0001$ vs. GEM. ${ }^{* \#+\prime} \mathrm{P}<0.001$ and

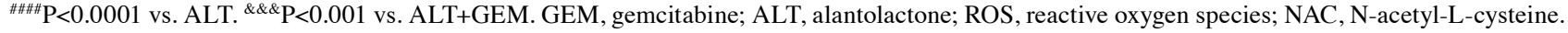

cell types, including prostate, bladder and lung cancer (28-30). To confirm whether ER stress is involved in ROS-mediated apoptosis induced by the test drugs, the effect of ALT and GEM on hallmarks of ER-associated apoptosis, including eIF2 $\alpha$ phosphorylation and CHOP expression, was determined in A549 and NCI-H520 cells with western blot analysis. As indicated in Fig. 5A, the levels of eIF2 $\alpha$ phosphorylation and CHOP expression were notably unregulated by ALT in A549 and NCI-H520 cells. Combination treatment with ALT and GEM notably increased the phosphorylation of eIF $2 \alpha$ and CHOP expression, compared with that caused by each drug alone (Fig. 5B). Furthermore, A549 and NCI-H520 cells were treated with ALT and GEM in the presence of NAC and the phosphorylation of eIF $2 \alpha$ and the expression of CHOP were then measured. It was revealed that NAC attenuated the phosphorylation of eIF $2 \alpha$ and the expression of CHOP induced by ALT and GEM (Fig. 5C). To further confirm whether ER stress is involved in GEM-mediated growth inhibition, the effects of TM, an ER stress agonist, on GEM-induced growth inhibition of A549 and NCI-H520 cells were assessed. As depicted in Fig. 5D, combination treatment with TM and GEM significantly decreased the cell viability compared with GEM alone. Collectively, these results revealed that ALT increases GEM-mediated apoptosis via ROS-mediated ER stress activation.

ALT sensitizes GEM-mediated cell apoptosis via ROS-mediated inhibition of the Akt/GSK3 $\beta$ pathway in A549 and NCI-H520 cells. The Akt pathway is an important pathway associated with ROS-mediated apoptosis in various cancer cell types, including bladder, lung and pancreatic cancer (31-34). To determine whether the Akt pathway is involved in ROS-mediated apoptosis, the effects of ALT and GEM on the levels of the expression of Akt, GSK3 $\beta$, p-Akt and p-GSK3 $\beta$ in A549 and NCI-H520 cells were determined by western blot analysis. As depicted in Fig. 6A, the levels of p-Akt and p-GSK3 $\beta$ (Ser 9) were notably decreased by ALT, but the levels of total Akt and GSK3 $\beta$ were not notably affected. Furthermore, combination treatment notably inhibited the levels of p-Akt and p-GSK3 $\beta$, compared with the mono-treatment groups (Fig. 6B). In another experiment, A549 and NCI-H520 cells were treated with LY294002, a PI3K inhibitor, and the levels of p-GSK3 $\beta$ and p-Akt were detected with western blot analysis. As depicted in Fig. 6C, LY294002 notably decreased the levels of p-GSK3 $\beta$ and p-Akt in A549 and NCI-H520 cells. To further determine the role of the Akt pathway in ROS-mediated cell apoptosis, A549 and NCI-H520 cells were pre-treated with NAC followed by the test drugs, and the effect on the levels of p-Akt was determined. As depicted in Fig. 6D, pre-treatment with NAC reduced the effect of co-treatment with ALT and GEM on p-Akt. The effect of pre-treatment with LY294002 on cell growth inhibition induced by GEM was then assessed. As depicted in Fig. 6E, LY294002 pre-treatment significantly increased the GEM-induced inhibition of A549 and NCI-H520 cell growth. Collectively, these results indicated that ALT increases GEM-mediated apoptosis via ROS-mediated activation of the Akt/GSK3 $\beta$ pathway.

\section{Discussion}

GEM, as a first-line chemotherapeutic drug, is frequently used for the treatment of a number of cancer types, including lung 
A

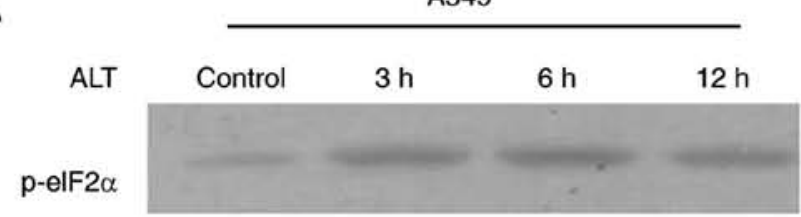

elF2 $\alpha$

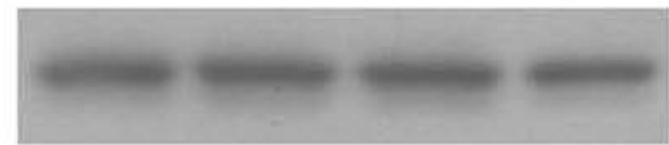

CHOP

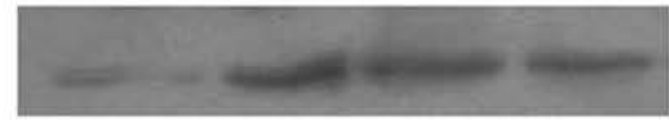

$\beta$-actin

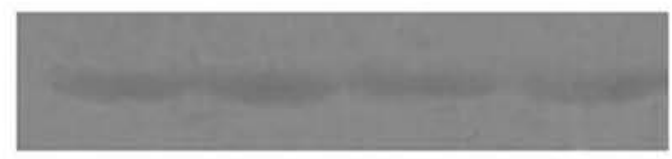

B

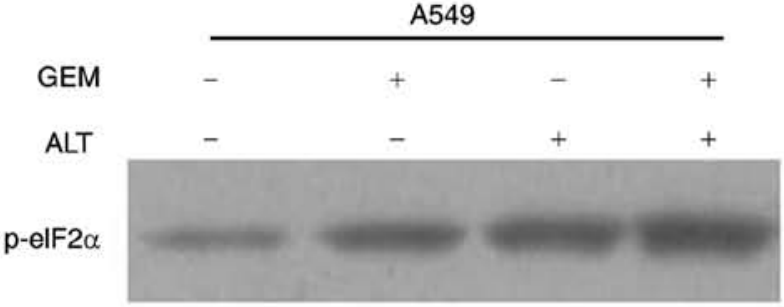

elF2 $\alpha$

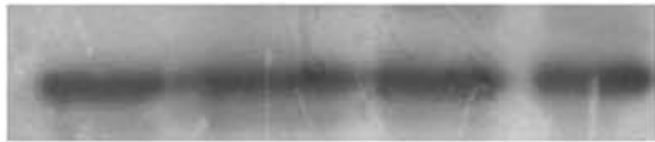

CHOP

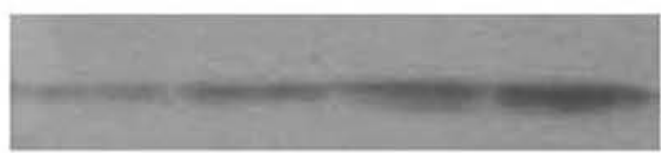

$\beta$-actin

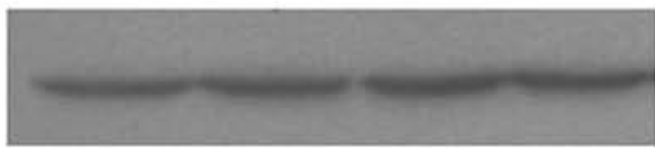

C

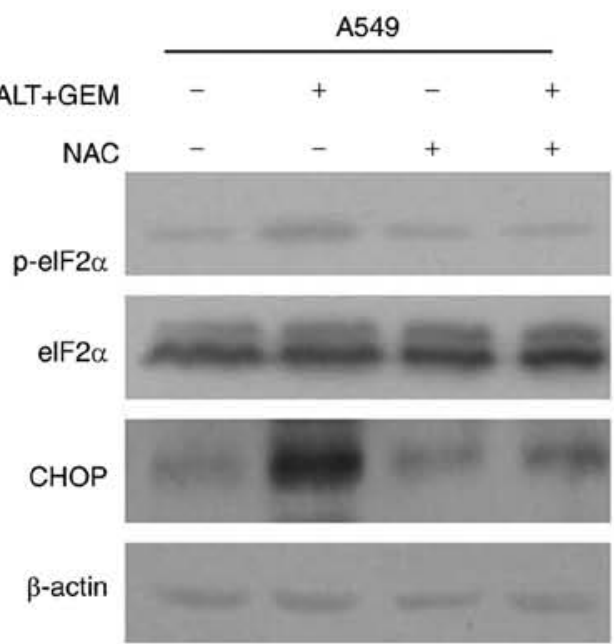

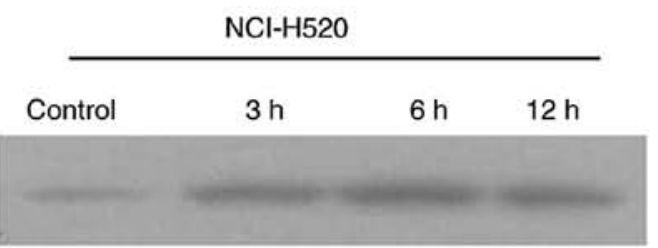
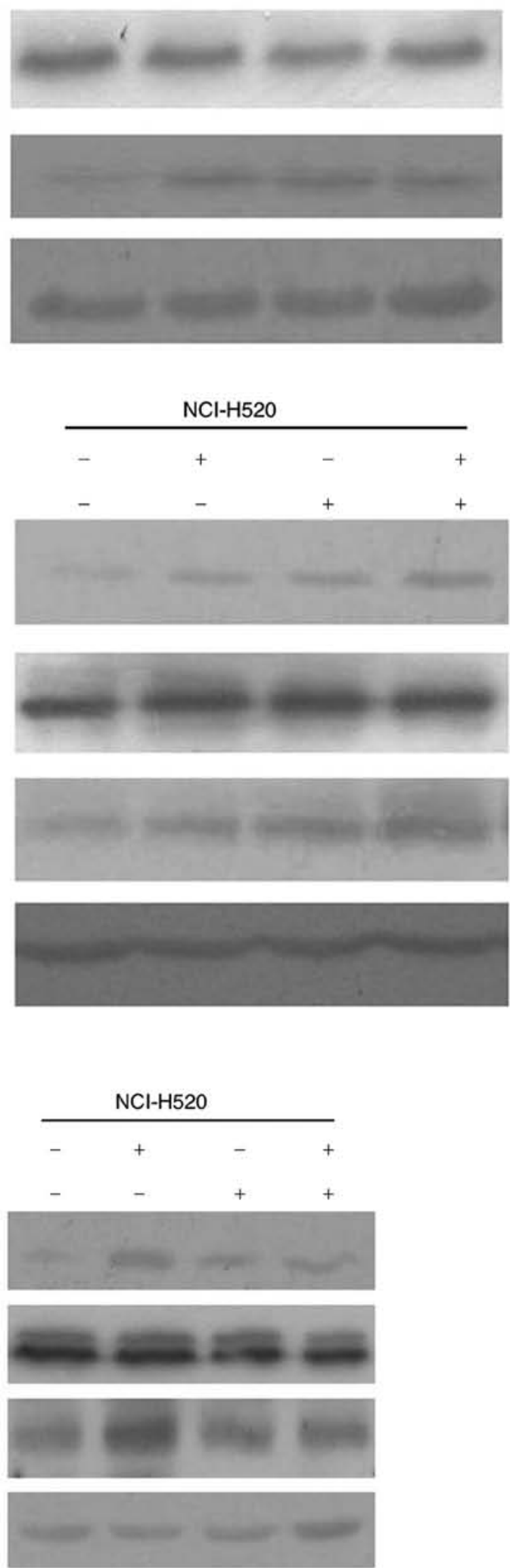

Figure 5. ALT enhances the anticancer activity of GEM in lung cancer cells via the reactive oxygen species-mediated endoplasmic reticulum stress pathway. (A) A549 cells were treated with ALT $(4 \mu \mathrm{m})$ and NCI-H520 cells were treated with ALT (40 $\mu \mathrm{m})$ for 3, 6 or $12 \mathrm{~h}$. (B) A549 and NCI-H520 cells were treated with ALT ( 4 or $40 \mu \mathrm{m})$ and/or GEM $(25 \mu \mathrm{m})$ for $12 \mathrm{~h}$. (C) A549 and NCI-H520 cells were pre-treated with NAC ( $8 \mathrm{mM})$ for $2 \mathrm{~h}$, followed by treatment with $\operatorname{ALT}(4$ or $40 \mu \mathrm{m})$ and GEM $(25 \mu \mathrm{m})$ for $12 \mathrm{~h}$. p-eIF2 $\alpha$ and CHOP were determined by western blot analysis and $\beta$-actin served as a loading control. 

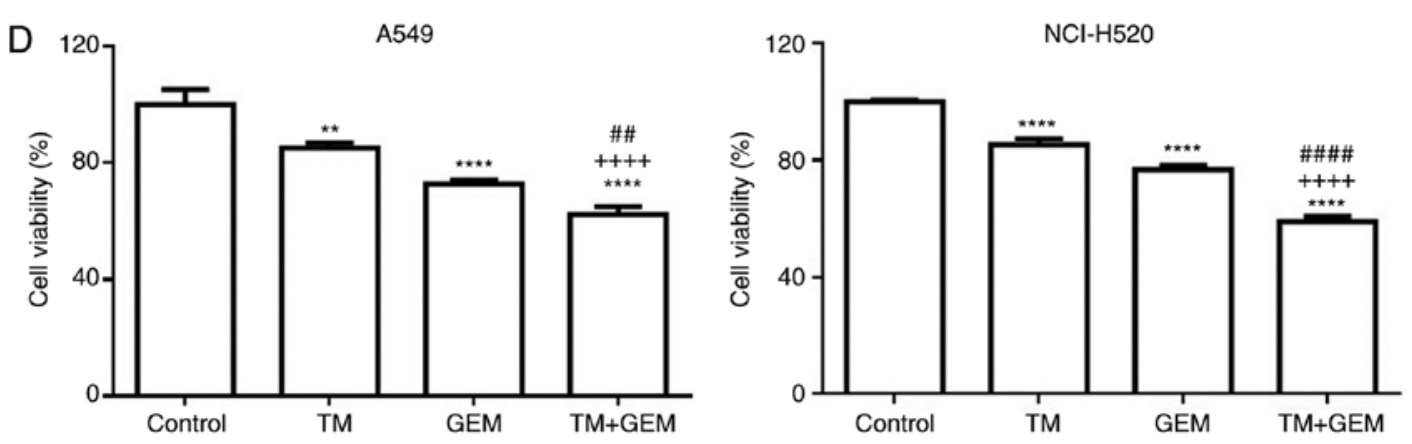

Figure 5. Continued. ALT enhances the anticancer activity of GEM in lung cancer cells via the reactive oxygen species-mediated endoplasmic reticulum stress pathway. (D) A549 and NCI-H520 cells were treated with TM $(4 \mu \mathrm{g} / \mathrm{ml})$ and/or GEM $(25 \mu \mathrm{m})$ for $24 \mathrm{~h}$ and the cell viability was determined with a Cell Counting Kit-8 assay. Values are expressed as the mean \pm standard deviation from three independent experiments. ${ }^{* * *} \mathrm{P}<0.01$ and ${ }^{* * * * *} \mathrm{P}<0.0001 \mathrm{vs}$. control. ${ }^{++++} \mathrm{P}<0.0001$ vs. TM. ${ }^{\# \#} \mathrm{P}<0.01$ and ${ }^{\# \# \# \# *} \mathrm{P}<0.0001$ vs. GEM. GEM, gemcitabine; ALT, alantolactone; NAC, N-acetyl-L-cysteine; p-eIF $2 \alpha$, phosphorylated eukaryotic initiation factor $2 \alpha$; CHOP, CCAAT-enhancer-binding protein homologous protein; TM, tunicamycin.

cancer(35,36). However, GEM resistance is common inlung cancer treatment and critically limits the outcome (37,38). Thus, novel strategies for the effective treatment of lung cancer are urgently required. Previous studies demonstrated that ALT has anticancer activity against various human cancer cell types, including colorectal, cervical and breast cancer (17-19). Additionally, it has been reported that ALT enhanced the chemosensitivity of cancer cells $(21,39)$. In the present study, it was investigated whether ALT and GEM have a synergistic effect on lung cancer. It was observed that ALT significantly inhibits the proliferation of A549 and NCI-H520 cells, and induces $\mathrm{G}_{0} / \mathrm{G}_{1}$ arrest and cell apoptosis in these cell lines. It was also demonstrated that ALT enhances the antitumor effect of GEM on A549 and NCI-H520 cells via ROS-mediated ER stress and the Akt/GSK3 $\beta$ pathway. In the future, the upstream mechanisms of the effects observed in the present study should be further investigated.

Previous studies indicated that induction of cell cycle arrest is an efficient strategy in anticancer therapy $(23,40,41)$. GEM has been reported to inhibit cell proliferation and induce S-phase arrest in lung cancer cells (42-44). It has also been reported that ALT induces $\mathrm{G} 2 / \mathrm{M}$-phase arrest and $\mathrm{G}_{1} / \mathrm{G}_{0}$-phase arrest in MDA-MB-231 breast cancer cells (19) and lung squamous cancer SK-MES-1 cells (20), respectively. In the present study, ALT or GEM induced S-phase arrest in A549 and NCI-H520 cells. Compared with ALT or GEM alone, the combination significantly increased the accumulation of A549 and NCI-H520 cells in the $\mathrm{S}$ phase. Additionally, cell cycle-associated protein analysis revealed that ALT alone or GEM alone caused an upregulation in the expression of cyclin-dependent kinase inhibitor p21 and a downregulation of cyclin A2. Furthermore, compared with ALT or GEM alone, their combination caused a notable upregulation in the expression of p21 and downregulation of cyclin A2. These results indicated that ALT enhanced the anti-proliferative effect of GEM in A549 and NCI-H520 cells via p21 and cyclin A2-mediated S-phase arrest.

Apoptosis is an important cellular process and numerous anticancer drugs, including paclitaxel, doxorubicin, carboplatin and curcumin, prevent tumor progression via inducing cell apoptosis (45-47). It is well known that ALT and GEM induce apoptosis in lung cancer $(21,48)$. The present results demonstrated that ALT and GEM induce apoptosis in A549 and NCI-H520 cells. The combination of the two drugs significantly increased the rate of apoptosis of A549 and
NCI-H520 cells, compared with that achieved with each drug alone. Cell apoptosis-associated protein analysis revealed that ALT or GEM may induce cell apoptosis by activation of caspase-3 in A549 and NCI-H520 cells. Cell apoptosis-associated protein analysis also revealed that the drug combination notably increases the level of activation of caspase-3. These results indicated that ALT enhances GEM-induced cell apoptosis by activation of caspase-3 in A549 and NCI-H520 cells.

High levels of ROS have been documented to induce apoptosis in various cancer types, including bladder, lung and cervical cancer, which have a notable role in cell apoptosis induced by anticancer drugs $(29,34,49)$. Previous research demonstrated that ALT induces cell apoptosis in various cancer types, including colorectal, cervical and breast cancer, via increasing the generation of ROS (17-19). Maryam et al (21) demonstrated that ALT enhances the chemosensitivity of A549 lung adenocarcinoma cells to doxorubicin via ROS generation. Cheng et al (16) also reported that resveratrol enhances the sensitivity of pancreatic cancer cells to GEM via inducing the accumulation of ROS. In the present study, an increase in ROS generation was observed in ALT- or GEM-treated A549 and NCI-H520 cells. Compared with ALT or GEM alone, their combination significantly increased the accumulation of ROS in A549 and NCI-H520 cells. Furthermore, the apoptosis of A549 and NCI-H520 cells treated by ALT and GEM combined was attenuated by NAC. Additionally, ALTand GEM-mediated upregulation of activation of caspase- 3 in A549 and NCI-H520 cells was also decreased by pre-treatment with NAC. Overall, the present results demonstrated that ALT enhanced GEM-induced cell apoptosis via increasing the accumulation of ROS in A549 and NCI-H520 cells.

The ER as a central cellular organelle is well known to regulate multiple cellular functions, including protein folding, protein maturation, ER quality control and the maintenance of cellular homeostasis $(50,51)$. The accumulation of misfolded proteins in the ER may disrupt ER function, cause ER stress and induce cell apoptosis (52). ER stress has become a novel target for potential anticancer drugs (53). It has also been demonstrated that increased ROS generation induced by anticancer drugs triggers ER stress-mediated apoptosis in various cancer types, including bladder, prostate and cervical cancer $(29,54,55)$. Maryam et al (21) reported that ALT enhances the chemosensitivity of A549 lung 
A

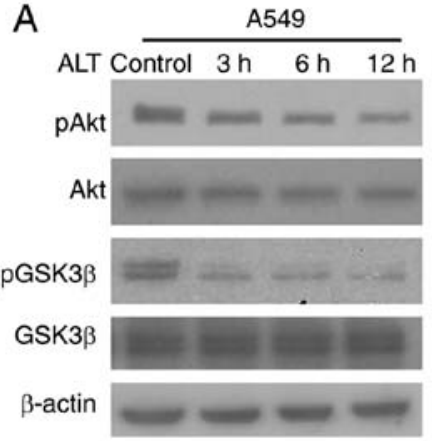

C

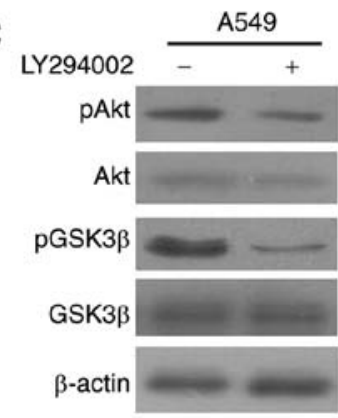

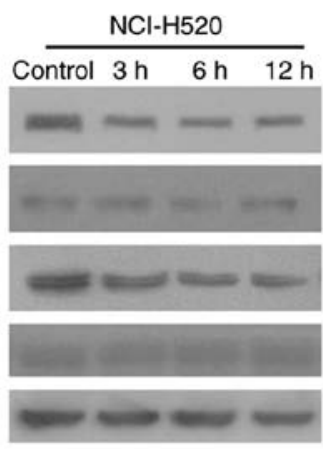

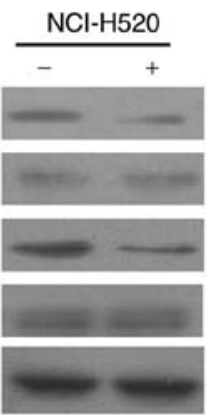

B
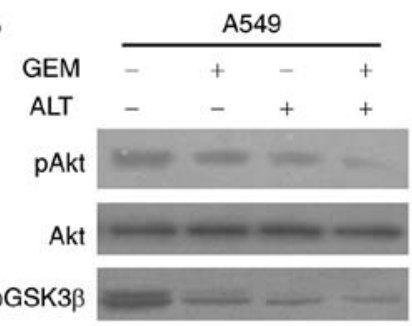

GSK3 $\beta$

$\beta$-actin

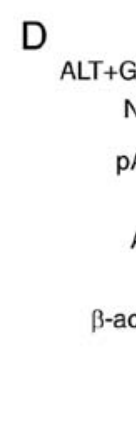

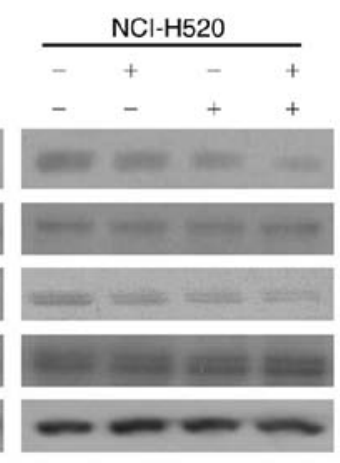

$\mathrm{NCl}-\mathrm{H} 520$
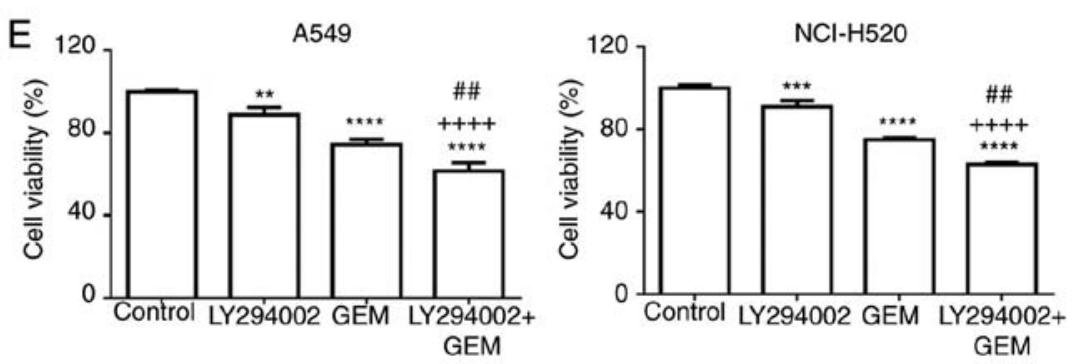

Figure 6. ALT enhances the anticancer activity of GEM in lung cancer cells via the reactive oxygen species-mediated Akt/GSK3 $\beta$ pathway. (A) A549 cells were treated with ALT $(4 \mu \mathrm{m})$ and NCI-H520 cells were treated with ALT (40 $\mu \mathrm{m})$ for 3, 6 or $12 \mathrm{~h}$. (B) A549 cells were treated with ALT (4 $\mu \mathrm{m})$ and/or GEM $(25 \mu \mathrm{m})$ and NCI-H520 cells were treated with ALT $(40 \mu \mathrm{m})$ and/or GEM $(25 \mu \mathrm{m})$ for $12 \mathrm{~h}$. (C) A549 and NCI-H520 cells were treated with LY294002 (4 $\mu \mathrm{m})$ for $12 \mathrm{~h}$. (D) A549 and NCI-H520 cells were pre-treated with NAC ( $8 \mathrm{mM}$ ) for $2 \mathrm{~h}$, followed by treatment with ALT (4 $\mu \mathrm{m})$ and/or GEM ( $25 \mu \mathrm{m})$ in A549 cells and treatment with ALT $(40 \mu \mathrm{m})$ and/or GEM $(25 \mu \mathrm{m})$ in NCI-H520 cells for $12 \mathrm{~h}$. p-Akt, Akt, p-GSK3 $\beta$ and GSK3 $\beta$ were determined by western blot and $\beta$-actin served as a loading control. (E) A549 and NCI-H520 cells were treated with LY294002 (4 $\mu \mathrm{m})$ and/or GEM (25 $\mu \mathrm{m})$ for $24 \mathrm{~h}$ and the cell viability was then determined with a Cell Counting Kit- 8 assay. Values are expressed as the mean \pm standard deviation from three independent experiments. ${ }^{* *} \mathrm{P}<0.01$, ${ }^{* * *} \mathrm{P}<0.001$ and ${ }^{* * * *} \mathrm{P}<0.0001$ vs. control. ${ }^{++++} \mathrm{P}<0.0001$ vs. LY294002. ${ }^{\# \#} \mathrm{P}<0.01$ vs. GEM. GEM, gemcitabine; ALT, alantolactone; p-GSK, phosphorylated glycogen synthase kinase; NAC, N-acetyl-L-cysteine.

adenocarcinoma cells to doxorubicin via the ROS-mediated ER stress apoptosis pathway. Consistent with this, the present study indicated that ALT caused a notable deregulation of ER stress-associated proteins, including increases in eIF2 $\alpha$ phosphorylation and CHOP expression in A549 and NCI-H520 cells. Combination treatment with ALT and GEM notably increased the phosphorylation of eIF $2 \alpha$ and CHOP expression, compared with that obtained with each drug alone. Furthermore, inhibition of ROS generation by NAC abrogated the ALT- and GEM-induced ER stress activation in A549 and NCI-H520 cells. Additionally, combination treatment with TM significantly enhanced the effect of GEM to decrease the viability of lung cancer cells. Collectively, these results indicated that ALT enhances GEM-mediated apoptosis via the ROS-mediated, ER stress-induced apoptosis pathway.

The Akt pathway is involved in regulating cell survival and death (56). Therefore, inhibition of the Akt signaling pathway has been considered an effective approach for the treatment of human cancer types, including prostate and gastric cancer $(57,58)$. It has been reported that the inhibition of Akt induced cancer cell apoptosis via inhibition of various downstream targets, including inhibition of the phosphorylation of GSK3 $\beta$ at Ser9 $(59,60)$. Furthermore, evidence indicated that increased ROS generation induced by anticancer drugs triggered cell apoptosis via inhibition of the Akt signaling pathway $(31,61)$. Li et al (62) reported that phenoxodiol enhances the antitumor activity of GEM against gallbladder cancer through suppressing the Akt pathway. Furthermore, Tuya et al (63) reported that trichosanthin enhances the antitumor effect of GEM via inhibition of the Akt pathway in NSCLC. In the present study, it was confirmed that ALT reduces the levels of p-Akt and p-GSK3 $\beta$ in A549 and NCI-H520 cells. Combination treatment of ALT and GEM notably reduced the levels of p-Akt and p-GSK $3 \beta$, compared with that in the mono-treatment groups. Furthermore, pre-treatment of NAC efficiently abrogated the combination treatment-induced reduction in the levels of p-Akt and p-GSK3 $\beta$. Additionally, LY294002 decreased the levels of 
p-GSK3 $\beta$ and increased GEM-induced cell growth inhibition in A549 and NCI-H520 cells. These results indicated that ALT enhances GEM-mediated apoptosis via ROS-mediated inhibition of the Akt/GSK3 $\beta$ pathway.

In conclusion, the present study demonstrated that ALT enhances the antitumor efficacy of GEM via the ROS-mediated inhibition of the Akt/GSK3 $\beta$ pathway and activation of the ER stress pathway in A549 and NCI-H520 cells. These results indicated that the combination of ALT and GEM may provide a potential clinical strategy for lung cancer treatment. Furthermore, these results will be further validated in in vivo experiments.

\section{Acknowledgements}

Not applicable.

\section{Funding}

This study was supported by grants from the Scientific Research Program Funded by Shaanxi Provincial Education Department (program no. 16JK1761), the National Key Research and Development Program (grant. no. 2016YFC0905001) and the National Natural Science Foundation of China (grant. no. 81471710).

\section{Availability of data and materials}

The datasets used and/or analyzed during the present study are available from the corresponding author on reasonable request.

\section{Authors' contributions}

JiqW and JiaW conducted the experiments and analyzed the data. JiqW made substantial contributions to the design of the present study and prepared the manuscript. YZ, XL, JizW, BL and YL performed the western blotting and analyzed the data. All authors read and approved the final manuscript.

\section{Ethics approval and consent to participate}

Not applicable.

\section{Patient consent for publication}

Not applicable.

\section{Competing interests}

The authors declare that they have no competing interests.

\section{References}

1. Molina JR, Yang P, Cassivi SD, Schild SE and Adjei AA: Non-small cell lung cancer: Epidemiology, risk factors, treatment, and survivorship. Mayo Clin Proc 83: 584-594, 2008.

2. Feldman MW and Roughgarden J: A population's stationary distribution and chance of extinction in a stochastic environment with remarks on the theory of species packing. Theor Popul Biol 7: 197-207, 1975.

3. Siegel RL, Miller KD and Jemal A: Cancer statistics, 2018. CA Cancer J Clin 68: 7-30, 2018.
4. Carvajal-Hausdorf D, Altan M, Velcheti V, Gettinger SN Herbst RS, Rimm DL and Schalper KA: Expression and clinical significance of PD-L1, B7-H3, B7-H4 and TILs in human small cell lung Cancer (SCLC). J Immunother Cancer 7: 65, 2019.

5. Torre LA, Siegel RL and Jemal A: Lung cancer statistics. Adv Exp Med Biol 893: 1-19, 2016.

6. Lee SH: Chemotherapy for lung cancer in the era of personalized medicine. Tuberc Respir Dis (Seoul): Dec 20, 2018 (Epub ahead of print).

7. Jia $\mathrm{Y}$ and $\mathrm{Xie}$ J: Promising molecular mechanisms responsible for gemcitabine resistance in cancer. Genes Dis 2: 299-306, 2015.

8. Qin JJ, Li X, Hunt C, Wang W, Wang H and Zhang R: Natural products targeting the p53-MDM2 pathway and mutant p53: Recent advances and implications in cancer medicine. Genes Dis 5: 204-219, 2018.

9. Albuquerque KRS, Pacheco NM, Del Rosario Loyo Casao T, de Melo FCSA, Novaes RD and Goncalves RV: Applicability of plant extracts in preclinical studies of melanoma: A systematic review. Mediators Inflamm 2018: 6797924, 2018.

10. Kim C and Kim B: Anti-cancer natural products and their bioactive compounds inducing ER stress-mediated apoptosis: A review. Nutrients 10: E1021, 2018.

11. Demain AL and Vaishnav P: Natural products for cancer chemotherapy. Microb Biotechnol 4: 687-699, 2011.

12. Meng LQ, Wang Y, Luo YH, Piao XJ, Liu C, Wang Y, Zhang Y, Wang JR, Wang H, Xu WT, et al: Quinalizarin induces apoptosis through reactive oxygen species (ROS)-mediated mitogen-activated protein kinase (MAPK) and signal transducer and activator of transcription 3 (STAT3) signaling pathways in colorectal cancer cells. Med Sci Monit 24: 3710-3719, 2018.

13. Liu F, Gao S, Yang Y, Zhao X, Fan Y, Ma W, Yang D, Yang A and Yu Y: Antitumor activity of curcumin by modulation of apoptosis and autophagy in human lung cancer A549 cells through inhibiting PI3K/Akt/mTOR pathway. Oncol Rep 39: 1523-1531, 2018.

14. Huang H, Xie H, Pan Y, Zheng K, Xia Y and Chen W: Plumbagin triggers ER stress-mediated apoptosis in prostate cancer cells via induction of ROS. Cell Physiol Biochem 45: 267-280, 2018.

15. Wang Y, Wang S, Liu J, Lu Y and Li D: Licoricidin enhances gemcitabine-induced cytotoxicity in osteosarcoma cells by suppressing the Akt and NF-kappaB signal pathways. Chem Biol Interact 290: 44-51, 2018.

16. Cheng L, Yan B, Chen K, Jiang Z, Zhou C, Cao J, Qian W, Li J, Sun L, Ma J, et al: Resveratrol-induced downregulation of NAF-1 enhances the sensitivity of pancreatic cancer cells to gemcitabine via the ROS/Nrf2 signaling pathways. Oxid Med Cell Longev 2018: 9482018, 2018.

17. Ding Y, Wang H, Niu J, Luo M, Gou Y, Miao L, Zou Z and Cheng Y: Induction of ROS overload by alantolactone prompts oxidative DNA damage and apoptosis in colorectal cancer cells. Int J Mol Sci 17: 558, 2016.

18. Jiang Y, Xu H and Wang J: Alantolactone induces apoptosis of human cervical cancer cells via reactive oxygen species generation, glutathione depletion and inhibition of the Bcl-2/Bax signaling pathway. Oncol Lett 11: 4203-4207, 2016.

19. Cui L, Bu W, Song J, Feng L, Xu T, Liu D, Ding W, Wang J, Li C, Ma B, et al: Apoptosis induction by alantolactone in breast cancer MDA-MB-231 cells through reactive oxygen species-mediated mitochondrion-dependent pathway. Arch Pharm Res 41: 299-313, 2018.

20. Zhao P, Pan Z, Luo Y, Zhang L, Li X, Zhang G, Zhang Y, Cui R, Sun M and Zhang X: Alantolactone induces apoptosis and cell cycle arrest on lung squamous cancer SK-MES-1 cells. J Biochem Mol Toxicol 29: 199-206, 2015.

21. Maryam A, Mehmood T, Zhang H, Li Y, Khan M and Ma T: Alantolactone induces apoptosis, promotes STAT3 glutathionylation and enhances chemosensitivity of A549 lung adenocarcinoma cells to doxorubicin via oxidative stress. Sci Rep 7: 6242, 2017.

22. Zhang Y, Wang J, Hui B, Sun W, Li B, Shi F, Che S, Chai L and Song L: Pristimerin enhances the effect of cisplatin by inhibiting the miR23a/Akt/GSK3beta signaling pathway and suppressing autophagy in lung cancer cells. Int J Mol Med 43: 1382-1394, 2019.

23. Razak NA, Abu N, Ho WY, Zamberi NR, Tan SW, Alitheen NB, Long $\mathrm{K}$ and Yeap SK: Cytotoxicity of eupatorin in MCF-7 and MDA-MB-231 human breast cancer cells via cell cycle arrest, anti-angiogenesis and induction of apoptosis. Sci Rep 9: 1514, 2019. 
24. Yang X, Zhao L, Zhang T, Xi J, Liu S, Ren L, Zheng Y and Zhang H: Protosappanin B promotes apoptosis and causes G1 cell cycle arrest in human bladder cancer cells. Sci Rep 9: 1048, 2019.

25. Geng YD, Zhang L, Wang GY, Feng XJ, Chen ZL, Jiang L and Shen AZ: Xanthatin mediates G2/M cell cycle arrest, autophagy and apoptosis via ROS/XIAP signaling in human colon cancer cells. Nat Prod Res: 1-5, 2018 (Epub ahead of print).

26. Zhou GZ, Li AF, Sun YH and Sun GC: A novel synthetic curcumin derivative MHMM-41 induces ROS-mediated apoptosis and migration blocking of human lung cancer cells A549. Biomed Pharmacother 103: 391-398, 2018.

27. Ma G, Luo W, Lu J, Ma DL, Leung CH, Wang Y and Chen X: Cucurbitacin $\mathrm{E}$ induces caspase-dependent apoptosis and protective autophagy mediated by ROS in lung cancer cells. Chem Biol Interact 253: 1-9, 2016.

28. Chen W, Li P, Liu Y, Yang Y, Ye X, Zhang F and Huang H: Isoalantolactone induces apoptosis through ROS-mediated ER stress and inhibition of STAT3 in prostate cancer cells. J Exp Clin Cancer Res 37: 309, 2018.

29. Xu Y, Tong Y, Ying J, Lei Z, Wan L, Zhu X, Ye F, Mao P, Wu X, Pan R, et al: Chrysin induces cell growth arrest, apoptosis, and ER stress and inhibits the activation of STAT3 through the generation of ROS in bladder cancer cells. Oncol Lett 15 : 9117-9125, 2018

30. Ge G, Yan Y and Cai H: Ginsenoside Rh2 inhibited proliferation by inducing ROS mediated ER stress dependent apoptosis in lung cancer cells. Biol Pharm Bull 40: 2117-2124, 2017.

31. Ji L, Zhong B, Jiang X, Mao F, Liu G, Song B, Wang CY, Jiao Y, Wang JP, Xu ZB, et al: Actein induces autophagy and apoptosis in human bladder cancer by potentiating ROS/JNK and inhibiting AKT pathways. Oncotarget 8: 112498-112515, 2017.

32. Ahn KI, Choi EO, Kwon DH, HwangBo H, Kim MY, Kim HJ, Ji SY, Hong SH, Jeong JW, Park C, et al: Induction of apoptosis by ethanol extract of Citrus unshiu Markovich peel in human bladder cancer T24 cells through ROS-mediated inactivation of the PI3K/Akt pathway. Biosci Trends 11: 565-573, 2017.

33. Lai ZQ, Ip SP, Liao HJ, Lu Z, Xie JH, Su ZR, Chen YL, Xian YF, Leung PS and Lin ZX: Brucein D, a naturally occurring tetracyclic triterpene quassinoid, induces apoptosis in pancreatic cancer through ROS-associated PI3K/Akt signaling pathway. Front Pharmacol 8: 936, 2017.

34. Guo CL, Wang LJ, Zhao Y, Liu H, Li XQ, Jiang B, Luo J, Guo SJ, Wu N and Shi DY: A novel bromophenol derivative BOS-102 induces cell cycle arrest and Apoptosis in human A549 lung cancer cells via ROS-Mediated PI3K/Akt and the MAPK signaling pathway. Mar Drugs 16: E43, 2018.

35. Amrutkar M and Gladhaug IP: Pancreatic cancer chemoresistance to gemcitabine. Cancers (Basel) 9: E157, 2017.

36. Li Y, Wang LR, Chen J, Lou Y and Zhang GB: First-line gemcitabine plus cisplatin in nonsmall cell lung cancer patients. Dis Markers 2014: 960458, 2014.

37. $\mathrm{Xu} \mathrm{B}$ and Tao ZZ: Piceatannol enhances the antitumor efficacy of gemcitabine in human A549 non-small cell lung cancer cells. Oncol Res 22: 213-217, 2014.

38. Gebregiworgis T, Bhinderwala F, Purohit V, Chaika NV Singh PK and Powers R: Insights into gemcitabine resistance and the potential for therapeutic monitoring. Metabolomics 14: 156, 2018.

39. Yao Y, Xia D, Bian Y, Sun Y, Zhu F, Pan B, Niu M, Zhao K, Wu Q, Qiao J, et al: Alantolactone induces G1 phase arrest and apoptosis of multiple myeloma cells and overcomes bortezomib resistance. Apoptosis 20: 1122-1133, 2015.

40. Wang Y, Ji P, Liu J, Broaddus RR, Xue F and Zhang W: Centrosome-associated regulators of the $\mathrm{G}(2) / \mathrm{M}$ checkpoint as targets for cancer therapy. Mol Cancer 8: 8, 2009.

41. Liu Y, Kang X, Niu G, He S, Zhang T, Bai Y, Li Y, Hao H, Chen C, Shou Z and Li B: Shikonin induces apoptosis and prosurvival autophagy in human melanoma A375 cells via ROS-mediated ER stress and p38 pathways. Artif Cells Nanomed Biotechnol 47: 626-635, 2019

42. Li J, Pan YY and Zhang Y: Synergistic interaction between sorafenib and gemcitabine in EGFR-TKI-sensitive and EGFR-TKI-resistant human lung cancer cell lines. Oncol Lett 5 : 440-446, 2013

43. Li J, Wang S, Su ZF and Yuan Y: Synergistic effects of sorafenib in combination with gemcitabine or pemetrexed in lung cancer cell lines with K-ras mutations. Contemp Oncol (Pozn) 20: 33-38, 2016.

44. Tang Y, Wang Y and Teng X: Sequence-dependent effect of gemcitabine and cisplatin on A549 non-small-cell lung cancer cells. Mol Med Rep 8: 221-226, 2013.
45. Huang YF, Zhu DJ, Chen XW, Chen QK, Luo ZT, Liu CC, Wang GX, Zhang WJ and Liao NZ: Curcumin enhances the effects of irinotecan on colorectal cancer cells through the generation of reactive oxygen species and activation of the endoplasmic reticulum stress pathway. Oncotarget 8: 40264-40275, 2017.

46. Broecker-Preuss M, Becher-Boveleth N, Muller S and Mann K: The BH3 mimetic drug ABT-737 induces apoptosis and acts synergistically with chemotherapeutic drugs in thyroid carcinoma cells. Cancer Cell Int 16: 27, 2016.

47. Gregoraszczuk EL, Rak-Mardyła A, Ryś J, Jakubowicz J and Urbański K: Effect of chemotherapeutic drugs on Caspase-3 activity, as a key biomarker for Apoptosis in ovarian tumor cell cultured as monolayer. A Pilot Study. Iran J Pharm Res 14 1153-1161, 2015.

48. Teng JP, Yang ZY,Zhu YM,Ni D, Zhu ZJ and Li XQ: Gemcitabine and cisplatin for treatment of lung cancer in vitro and vivo. Eur Rev Med Pharmacol Sci 22: 3819-3825, 2018

49. Seervi M, Rani A, Sharma AK and Santhosh Kumar TR: ROS mediated ER stress induces Bax-Bak dependent and independent apoptosis in response to Thioridazine. Biomed Pharmacother 106: 200-209, 2018.

50. Yadav RK, Chae SW, Kim HR and Chae HJ: Endoplasmic reticulum stress and cancer. J Cancer Prev 19: 75-88, 2014.

51. Chipurupalli S, Kannan E, Tergaonkar V, D'Andrea R and Robinson N: Hypoxia induced ER stress response as an adaptive mechanism in cancer. Int J Mol Sci 20: E749, 2019.

52. Wang $M$ and Kaufman RJ: The impact of the endoplasmic reticulum protein-folding environment on cancer development. Nat Rev Cancer 14: 581-597, 2014.

53. Logothetis C, Aparicio A and Thompson TC: ER stress in prostate cancer: A therapeutically exploitable vulnerability? Sci Transl Med 10: eaat3975, 2018.

54. Wu S, Yang Y, Li F, Huang L, Han Z, Wang G, Yu H and Li H: Chelerythrine induced cell death through ROS-dependent ER stress in human prostate cancer cells. Onco Targets Ther 11: 2593-2601, 2018

55. Lin CL, Lee CH, Chen CM, Cheng CW, Chen PN, Ying TH and Hsieh YH: Protodioscin induces Apoptosis through ROS-Mediated endoplasmic reticulum stress via the JNK/p38 activation pathways in human cervical cancer cells. Cell Physiol Biochem 46: 322-334, 2018.

56. Madhunapantula SV, Mosca PJ and Robertson GP: The Akt signaling pathway: An emerging therapeutic target in malignant melanoma. Cancer Biol Ther 12: 1032-1049, 2011.

57. Hong SW, Shin JS, Moon JH, Kim YS, Lee J, Choi EK, Ha SH, Lee DH, Chung HN, Kim JE, et al: NVP-BEZ235, a dual $\mathrm{PI} 3 \mathrm{~K} / \mathrm{mTOR}$ inhibitor, induces cell death through alternate routes in prostate cancer cells depending on the PTEN genotype. Apoptosis 19: 895-904, 2014.

58. Liu M, Li CM, Chen ZF, Ji R, Guo QH, Li Q, Zhang HL and Zhou YN: Celecoxib regulates apoptosis and autophagy via the PI3K/Akt signaling pathway in SGC-7901 gastric cancer cells. Int J Mol Med 33: 1451-1458, 2014

59. Xue M, Ji X, Xue C, Liang H, Ge Y, He X, Zhang L, Bian K and Zhang L: Caspase-dependent and caspase-independent induction of apoptosis in breast cancer by fucoidan via the PI3K/AKT/GSK $3 \beta$ pathway in vivo and in vitro. Biomed Pharmacother 94: 898-908, 2017.

60. Yang Q, Wen L, Meng Z and Chen Y: Blockage of endoplasmic reticulum stress attenuates nilotinib-induced cardiotoxicity by inhibition of the Akt-GSK3 $\beta$-Nox 4 signaling. Eur J Pharmacol 822: 85-94, 2018.

61. Song X, Wang Z, Liang H, Zhang W, Ye Y, Li H, Hu Y, Zhang Y, Weng H, Lu J, et al: Dioscin induces gallbladder cancer Apoptosis by inhibiting ROS-Mediated PI3K/AKT signalling. Int J Biol Sci 13: 782-793, 2017

62. Li Y, Huang X, Huang Z and Feng J: Phenoxodiol enhances the antitumor activity of gemcitabine in gallbladder cancer through suppressing Akt/mTOR pathway. Cell Biochem Biophys 70: $1337-1342,2014$

63. Tuya N, Wang Y, Tong L, Gao W, Yu R and Xue L: Trichosanthin enhances the antitumor effect of gemcitabine in non-small cell lung cancer via inhibition of the PI3K/AKT pathway. Exp Ther Med 14: 5767-5772, 2017.

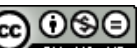

This work is licensed under a Creative Commons Attribution-NonCommercial-NoDerivatives 4.0 International (CC BY-NC-ND 4.0) License. 